Introduction to Technology Stewardship for Agricultural Extension and Advisory Services 


\title{
Introduction to Technology Stewardship for Agricultural Extension and Advisory Services
}

\author{
Course Workbook
}

GORDON GOW

HELEN HAMBLY ODAME, UVASARA DISSANAYEKE, UDITH JAYASINGHE-MUDALIGE, ROB MCMAHON, NUWAN WAIDAYANTHA, AND CHANDANA JAYATHILAKE 


\section{(ㄷ) (i) (2) (2)}

Introduction to Technology Stewardship for Agricultural Extension and Advisory Services by Gordon Gow is licensed under a Creative Commons Attribution-NonCommercial-ShareAlike 4.0 International License, except where otherwise noted. 



\section{Contents}

An Introduction to Technology Stewardship for Agricultural Communities of Practice

Course Workbook

Gordon Gow

Introduction

Table of Contents

$\underline{\text { Session I: Principles and Practices of Technology Stewardship }}$

Worksheet 1.1 (a): Discussion on Communities of Practice 4

Worksheet 1.1(b): Discussion on Principles of Stewarding 6

Worksheet 1.2: Classifying Community Priorities 7

Worksheet 1.3: Choosing an ICT Tool 11

Worksheet 1.4: Planning and Managing a Campaign 17

$\underline{\text { Session 2: Engaging Your Community and Creating a Campaign }}$

Worksheet 2.1: Identify a Community of Practice 21

Worksheet 2.2: The Technology Steward 23

Worksheet 2.3: Community Characteristics 26

Worksheet 2.4: Community Consultation 33

Worksheet 2.5: Establishing the Campaign Goal 36

Worksheet 2.6: Create a Use-Case Scenario 41

Session 3: Choosing an ICT Platform and Rapid Prototyping

Worksheet 3.1: Matching Activities with ICT Tools 46

Worksheet 3.2: Choosing an Acquisition Strategy 47

Worksheet 3.3: Identify your ICT Platforms 51

Worksheet 3.4: Matching the Tools with the Platform 57

Worksheet 3.5: Evaluate the Platform 58

Worksheet 3.6: Prepare and Test the Prototype 61

$\underline{\text { Session 4: Planning and Managing a Campaign }}$

Worksheet 4.1: Planning Timeline and Checkpoints 64

Worksheet 4.2: Campaign Planning Checklist 65 
Worksheet 4.3: Creating a Campaign Evaluation Plan

Worksheet 4.4: Collecting Information

Worksheet 4.5: The Campaign Plan

Worksheet 4.6: Reporting Back to the Community 


\title{
An Introduction to Technology Stewardship for Agricultural Communities of Practice
}

\author{
Course Workbook
}

GORDON GOW

Additional Contributors:

Chandana Jayathilake, Wayamba University of Sri Lanka

Helen Hambly Odame, University of Guelph

Uvasara Dissanayeke, University of Peradeniya

Rob McMahon, University of Alberta

Udith Jayasinghe-Mudalige, Wayamba University of Sri Lanka

Nuwan Waidayantha, Sahana Software Foundation

Revised: March 2019

Portions of this workbook are adapted from Digital Habitats: Stewarding Technology for Communication.

The authors would like to acknowledge Etienne Wenger, Nancy White, and John D. Smith for the important contribution their book has made to the development of this course.

This work is licensed under a $\underline{\text { Creative Commons Attribution-NonCommercial-ShareAlike } 4.0 \text { International License. }}$ 


\section{Introduction}

Technology stewardship is a leadership role that almost any practitioner can assume. In this role, a technology steward is someone who works with a community of practice (COP) to encourage the adoption and use of digital technologies for communications, training, and knowledge transfer.

Technology Stewards need to know how to engage their community members to identify opportunities and challenges; they need to be able to acquire and configure appropriate digital information and communication technologies (ICT) platforms to support innovative practices; and they need to be able to evaluate and report the outcome of their efforts back to the community and to organizational sponsors. Technology stewardship is not the same as 'IT support'. It is a leadership role intended to help members of a community of practice to better understand and make informed choices when incorporating ICT for communication and knowledge sharing.

This course is designed to introduce you to a leadership strategy that will help you understand and assume the role of a technology steward with your COP. The course sessions will present a process and set of activities that will equip you with the means necessary to analyze the communication challenges facing a COP, identify and assess a range of technology choices to address those challenges, and undertake an exploratory campaign to respond to those challenges using low-cost ICTs.

The medium-range goal of implementing a Technology Stewardship program is to promote experimentation with digital ICTs and to build capacity for innovation within a community of practice. Technology Stewards should aim to cultivate a culture of innovative thinking among their community members with the long term objective of enhancing the range of real choices available to practitioners when it comes to sharing information and mobilizing knowledge with digital ICTs.

For textbook errors or omissions, please email Gordon A. Gow at ggow@ualberta.ca.

1 | Introduction 


\title{
TABLE OF CONTENTS
}

\author{
Session 1: Principles and Practices of Technology Stewardship \\ 1.1(a): Discussions on Communities of Practice \\ 1.1(b): Discussions on Principles of Stewarding \\ 1.2: Classifying Community Priorities and Campaign Orientation \\ 1.3: Choosing an ICT Tool \\ 1.4: Planning and Managing a Campaign
}

\author{
Session 2: Engaging your Community and Creating a Campaign \\ 2.1: Identify a Community of Practice \\ 2.2: The Technology Steward \\ 2.3: Community Characteristics \\ 2.4: Community Consultation \\ 2.5: Establishing the Campaign Goal \\ 2.6: Create a Use-Case Scenario
}

\author{
Session 3: Choosing an ICT Platform and Rapid Prototyping \\ 3.1: Matching Activities with ICT Tools \\ 3.2: Choosing an Acquisition Strategy \\ 3.3: Identify your ICT Platforms \\ 3.4: Match the Tool(s) with a Platform \\ 3.5: Evaluate the Platform \\ 3.6: Prepare and Test the Prototype \\ Session 4: Planning and Managing a Campaign \\ 4.1: Planning Timeline and Checkpoints \\ 4.2: Campaign Planning Checklist \\ 4.3: Creating a Campaign Evaluation Plan \\ 4.4: Collecting Information \\ 4.5: Managing the Campaign \\ 4.6: Reporting Back to the Community
}




\section{SESSION I: PRINCIPLES AND PRACTICES OF TECHNOLOGY STEWARDSHIP}

\section{WORKSHEETS}

1.1(a): Discussions on Communities of Practice

1.1(b): Discussions on Principles of Stewarding

1.2: Classifying Community Priorities and Campaign Orientation

1.3: Choosing an ICT Tool

1.4: Planning and Managing a Campaign 


\section{Worksheet I.I (a): Discussion on Communities of Practice}

Let's begin with identifying a Community of Practice in the case study and thinking about who might fit the role of technology steward.

Communities of practice are groups of people who share a concern, a set of problems, or a passion about a topic, and who deepen their knowledge and expertise in this area by interacting on an ongoing basis.

-Wenger E., R. McDermott, W. Snyder (2002). Cultivating Communities of Practice. Harvard Business Press. (p. 4)

Tech stewards most often are members of the community they serve. They just happen to pay attention to technology issues in the community's life.

-Wenger, E., N. White, J. Smith (2008). Digital Habitats: Stewarding Technology for Communities. CP Square. (p.25)

\section{Review Case Study PART A}

\section{Download PDF (1.1a - Identifying a Community of Practice)}

Discuss each of these questions in your group and write down your responses.

- What community of practice (COP) is identified in the case study?

- What other possible communities of practice might exist in this region? Consider the various issues and concerns listed in the case study booklet. A COP might be narrowly focused on a specific domain. Or it might have a more general focus.

- List two ways that members of a COP might interact to share expertise as a group? 
- Who is filling the role of technology steward in the case study?

- Who else might be able to fill the role of technology steward in the case study?

- Who understands the community well? Who is trusted?

- Who is likely to be paying attention to ICT use in the community? 


\section{Worksheet I.I(b): Discussion on Principles of Stewarding}

Let's examine the community's priority, the ICT tool, and the principles that will guide the tech steward in helping the community in the case study.

Review Case Study PART B and PART C

Discuss each of these questions in your group and write down your responses based on details in the case study.

Download PDF (1.1b Principles of Stewarding)

\begin{tabular}{|c|c|}
\hline Review the Key Principles of Stewarding & Discuss with your group and write your notes here \\
\hline $\begin{array}{l}\text { Vision before technology } \\
\text { What is the priority need that the community members identified } \\
\text { at the meeting? }\end{array}$ & \\
\hline $\begin{array}{l}\text { Keep it simple } \\
\text { What is the most obvious choice of ICT tool for this community to } \\
\text { address that need? What are some of the advantages? What are the } \\
\text { disadvantages of this choice? }\end{array}$ & \\
\hline $\begin{array}{l}\text { Understand failure/build on success } \\
\text { What are some signs of success if this choice of ICT tool is } \\
\text { effective? What kind of information will you need to collect to } \\
\text { determine if it is a success? } \\
\text { True or false: the chosen ICT tool must perform as intended for it } \\
\text { to be a successful campaign. } \\
\text { If true, then why? If false, then why not? }\end{array}$ & \\
\hline $\begin{array}{l}\text { Use the knowledge around you } \\
\text { Who in the community, or elsewhere, could assist the technology } \\
\text { steward in this case? }\end{array}$ & \\
\hline
\end{tabular}

Adapted from Wenger, White \& Smith (2009). Digital Habitats: Stewarding Technology for Communities. Portland: CPSquare. 


\section{Worksheet I.2: Classifying Community Priorities}

Let's classify and rank the identified priorities of the community of practice in the case study into one or more orientations.

Review Case Study PART D

Use this Spider Diagram to plot out the two priority orientations described in the case study.

Use the scale on the diagram to rank each orientation, with 5 being most important. Based on the details in the case study, plot a third orientation that might be important to the community.

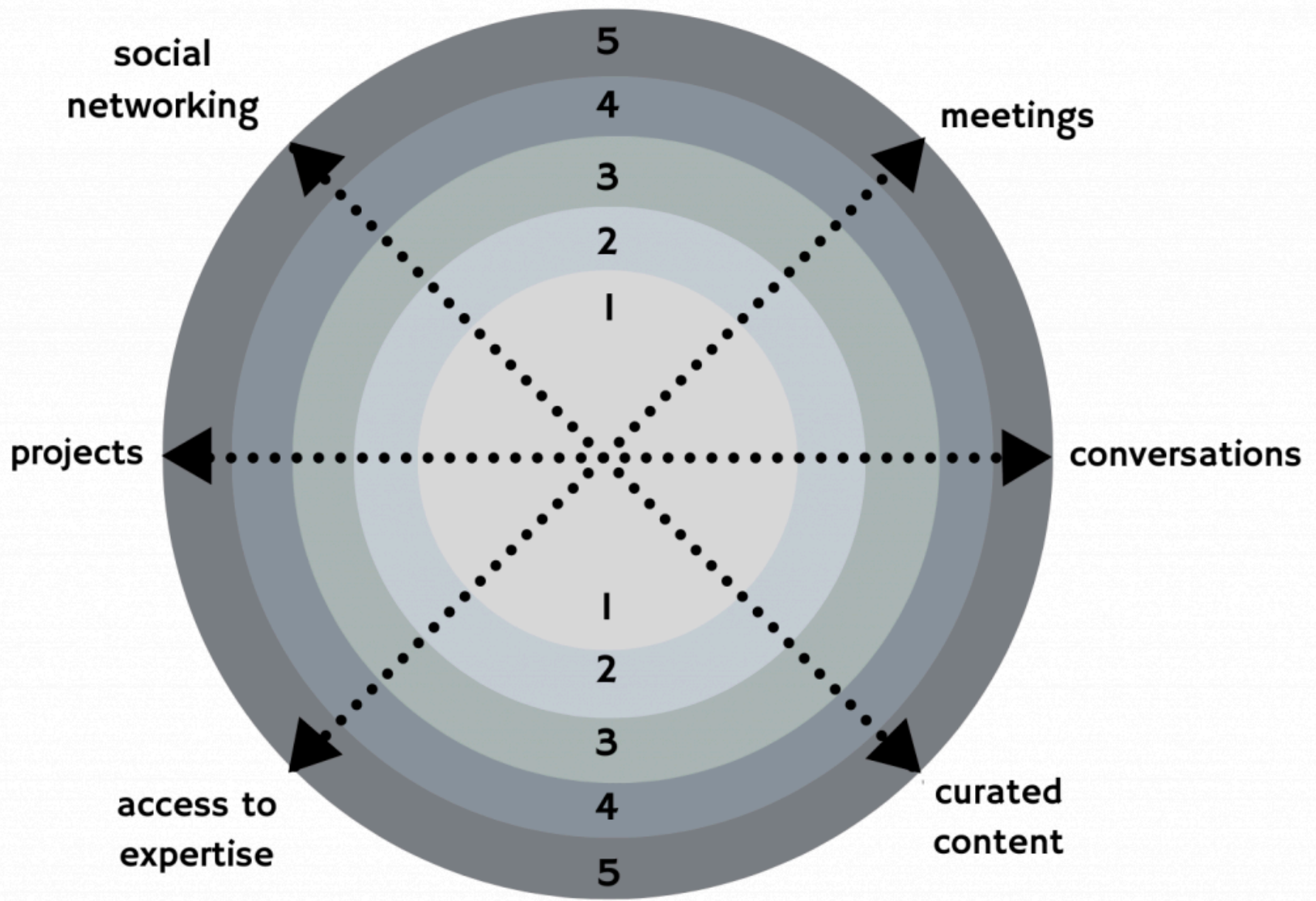

Adapted from Wenger, White \& Smith (2009). Digital Habitats: Stewarding Technology for Communities. CPsquare. 
In the following table circle the primary orientation(s) for some other examples with different kinds of priorities.

Download PDF (1.2 Classifying Community Priorities) 


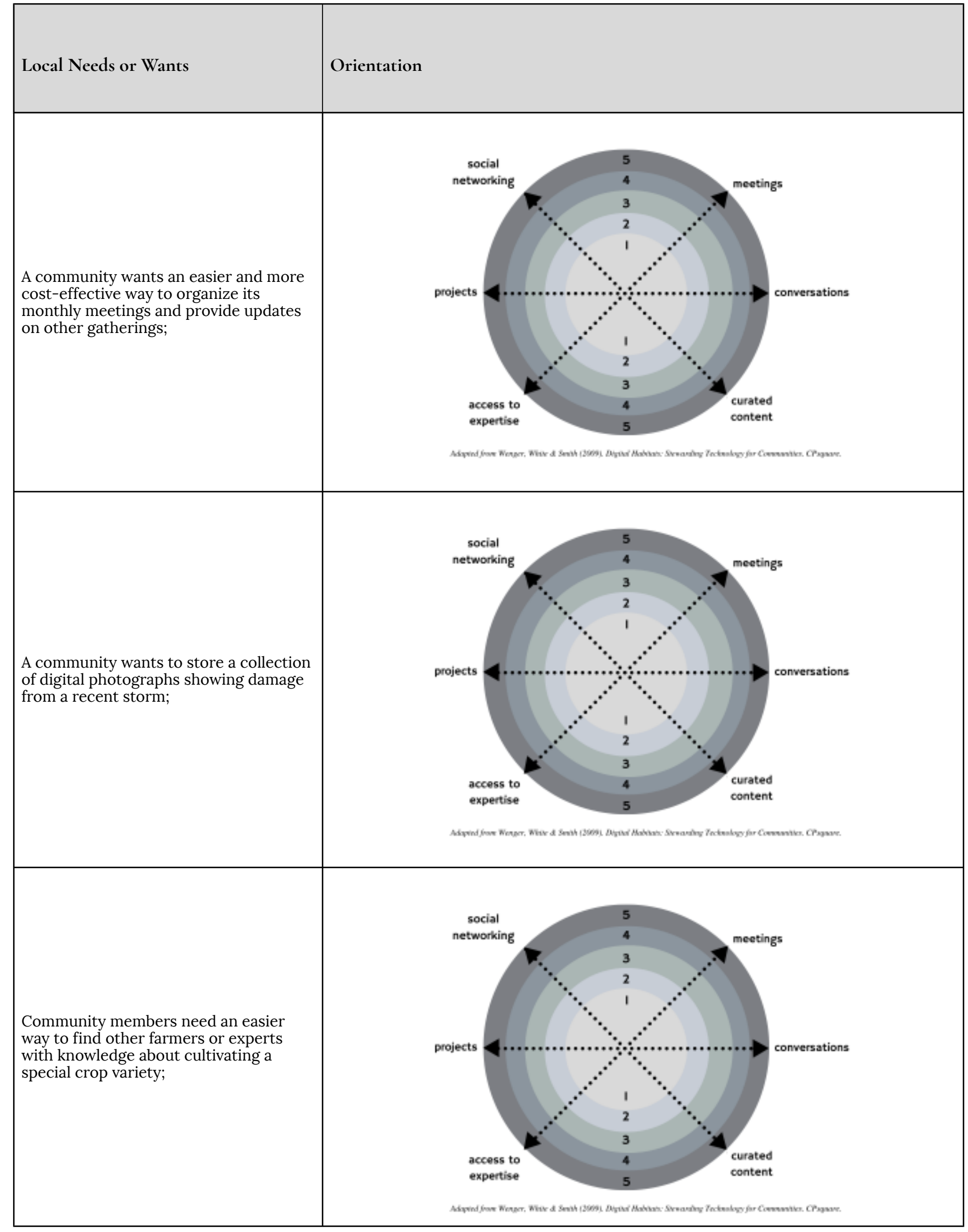




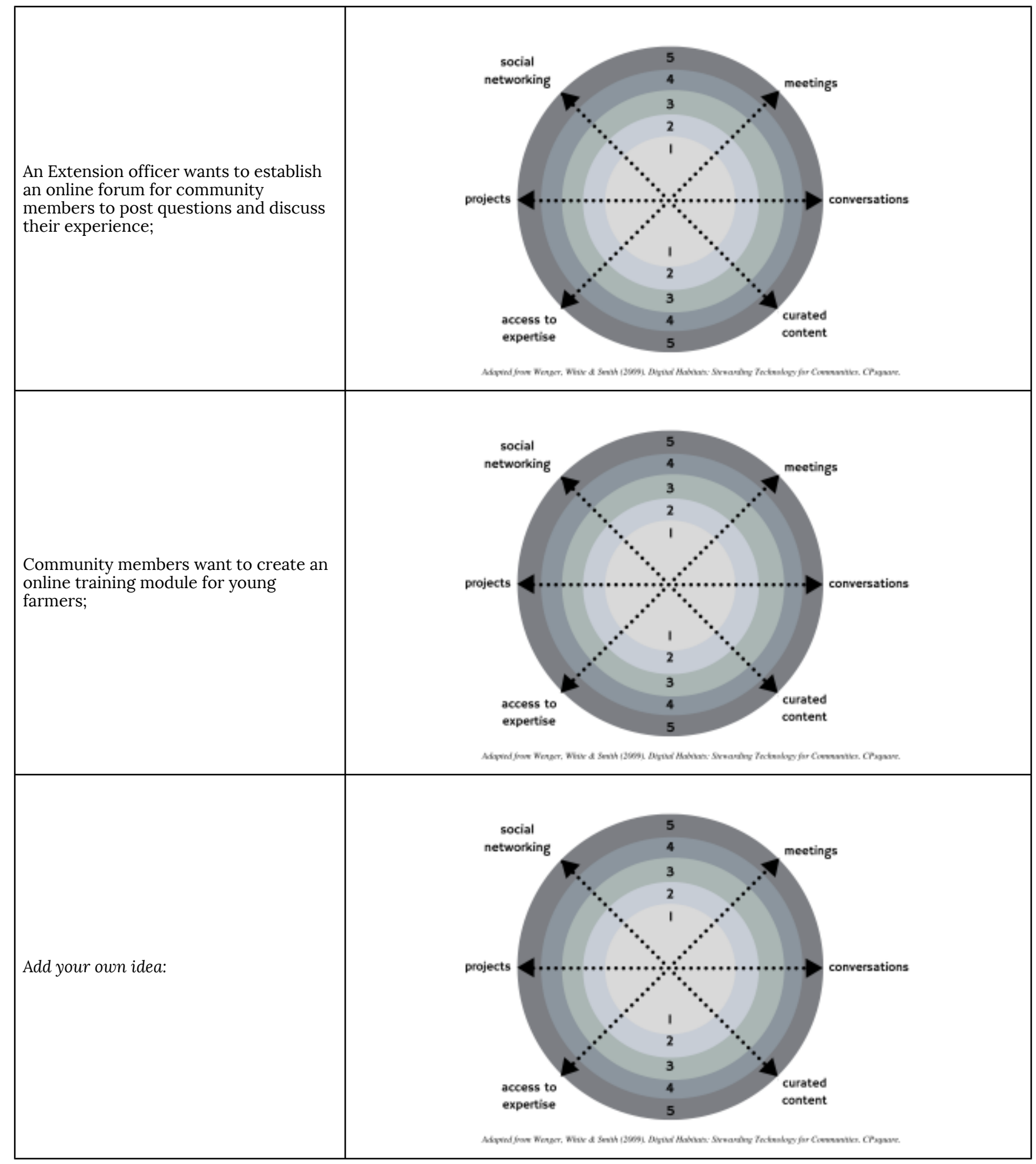




\section{Worksheet I.3: Choosing an ICT Tool}

When choosing an ICT tool, it is important that it is fit for purpose. In other words, the tool and its features must be able to support the activity for which it will be used.

Note that an ICT tool is not the same as a platform. A platform or 'app' (e.g., Google, Facebook) generally includes a set of ICT tools.

\section{Review Case Study PART E}

The Tools Landscape diagram helps to find a good fit between the choice of ICT tool and the community dynamic and activities it can support. This diagram already includes some examples.

Locate the ICT tool from the case study on this diagram. Does it favour participation or documentation? Synchronous or asynchronous communication? Individual or group action?

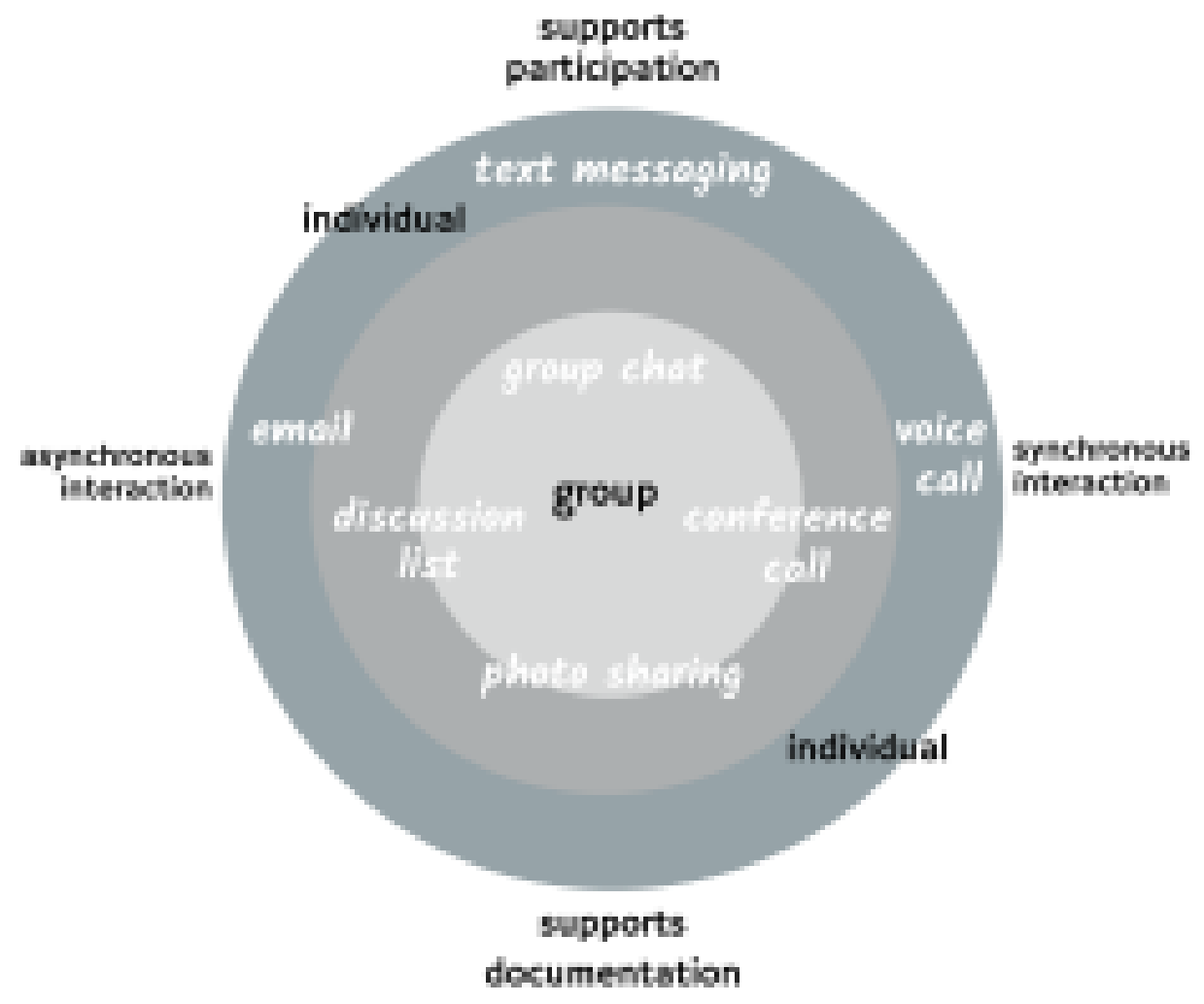

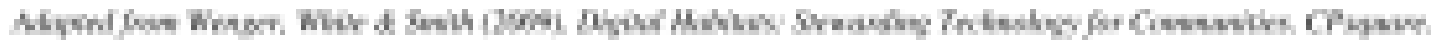




\section{Understanding the Tools Landscape: Exercises}

Look at the table below and read the activity descriptions. Then turn to the next set of pages and circle the ICT tool from the Tools Landscape chart that best fits each of the described activities.

\section{Download PDF (1.3 Understanding the Tools Exercises)}

Note: In some examples, there may be more than one ICT tool that is required to support the activity.

\begin{tabular}{|l|l|}
\hline Exercise & Campaign Description \\
\hline A & A radio station runs a campaign and asks its listeners to send questions for its weekly farm radio broadcast; \\
\hline B & $\begin{array}{l}\text { The community members want to be able to report any risks or hazards they observe in the area. They } \\
\text { would like to see these reports plotted on a map and posted on the Internet for government officers to see; }\end{array}$ \\
\hline C & Farmers would like to be able to have easy access to real-time market prices on crops; \\
\hline D & $\begin{array}{l}\text { An extension officer wants to create a collection of images and short video clips in response to questions } \\
\text { from farmers about their crops. The officer would like farmers to be able to rate and comment on the items } \\
\text { in the collection. }\end{array}$ \\
\hline
\end{tabular}

\section{Exercise A}

Campaign Description: A radio station runs a campaign and asks its listeners to send questions for its weekly farm radio broadcast.

Circle the ICT tool(s) that are a good fit for this purpose:

Can you think of a platform or app that includes this tool(s)? Write it down here: 
Exercise B

Campaign Description: The community members want to be able to report any risks or hazards they observe in the area. They would like to see these reports plotted on a map and posted on the Internet for government officers to see;

Circle the ICT tool(s) from that are a good fit for this purpose:

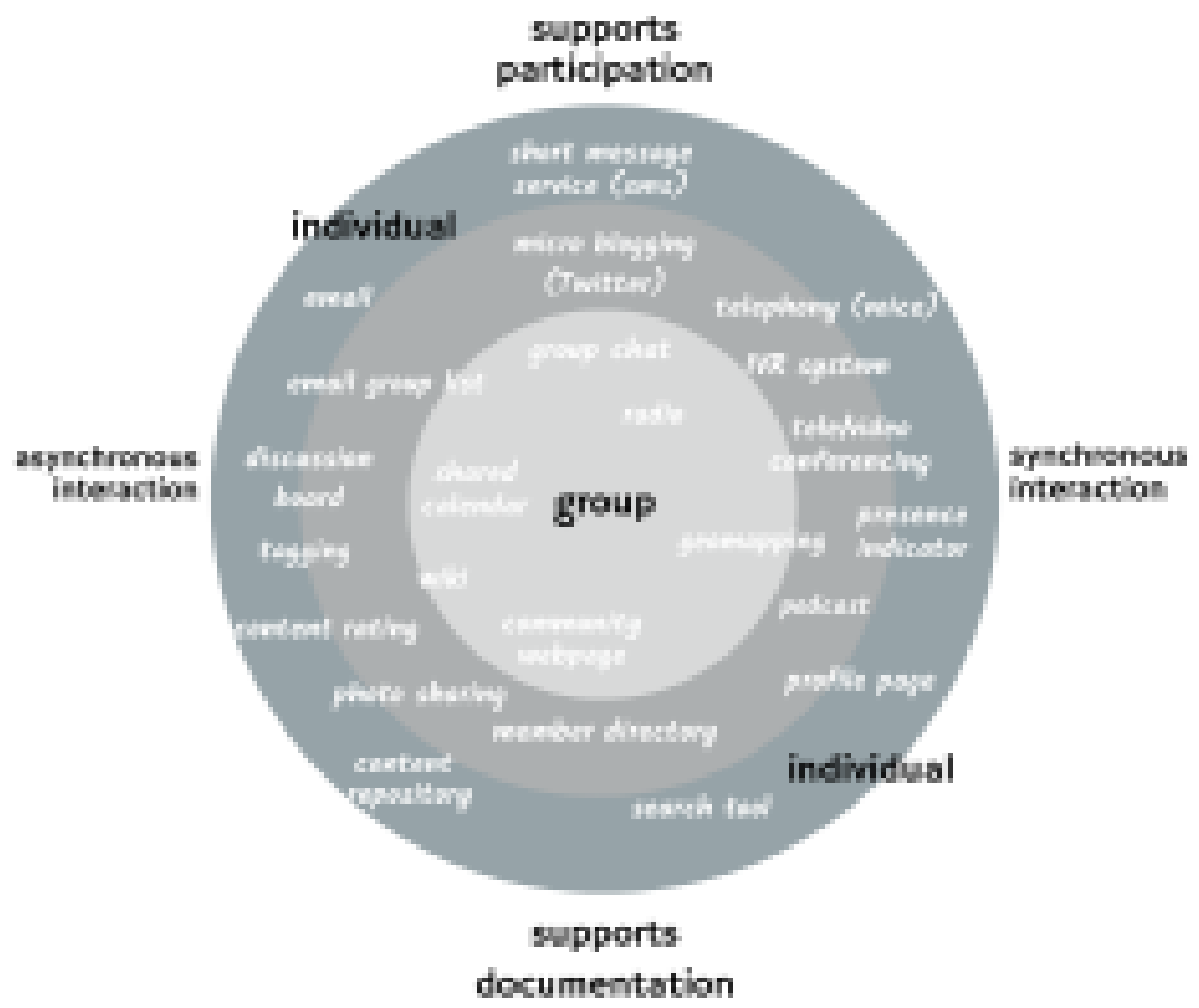

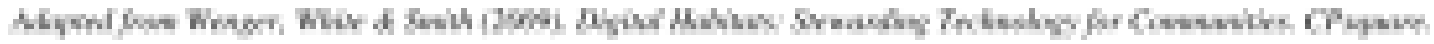

Can you think of a platform or app that includes this tool(s)? Write it down here: 
Exercise C

Campaign Description: Farmers would like to be able to have easy access to real-time market prices on crops.

Circle the ICT tool(s) from that are a good fit for this purpose

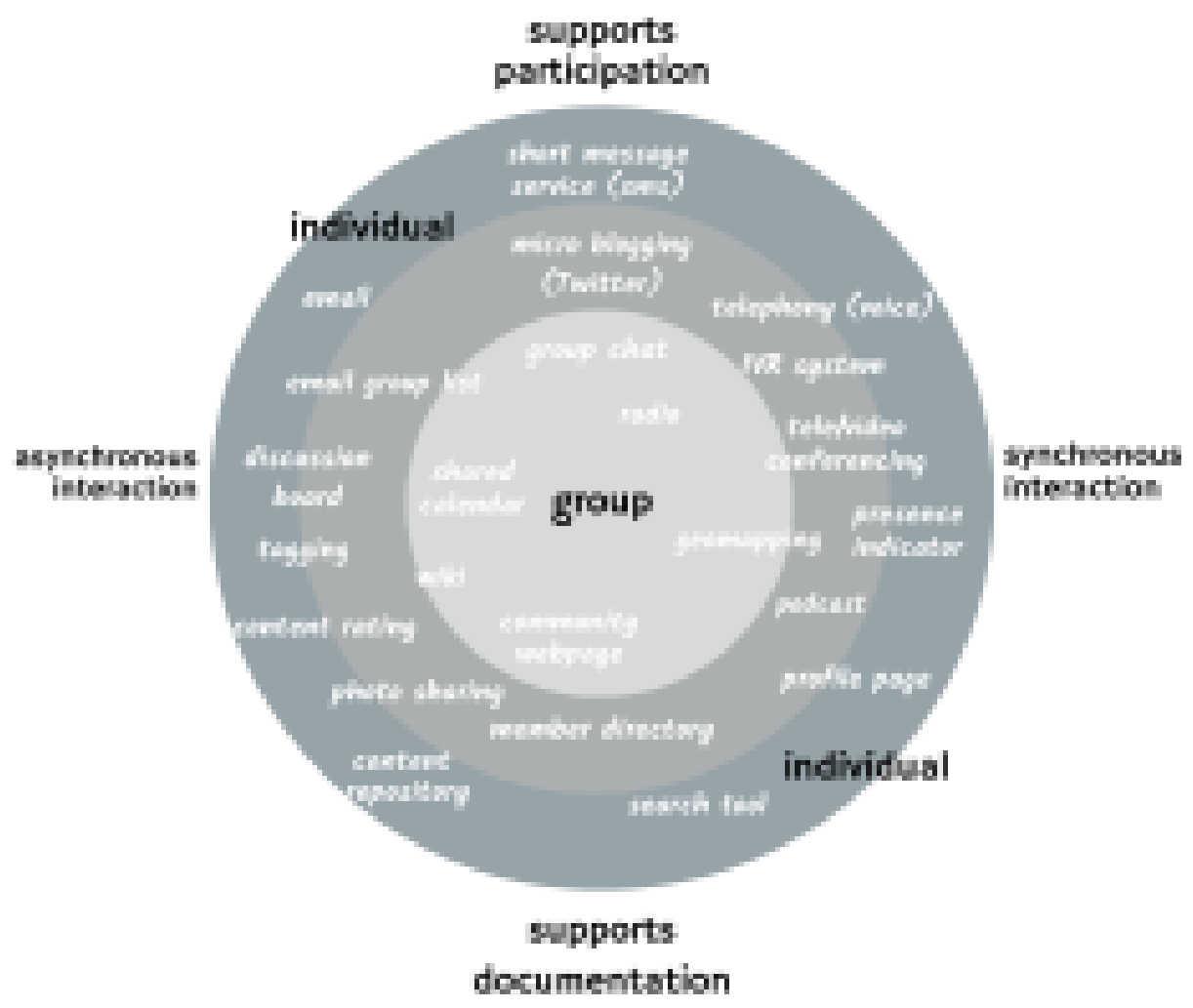

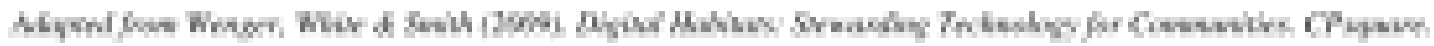

Can you think of a platform or app that includes this tool(s)? Write it down here: 
Exercise D

Campaign Description: An extension officer wants to create a collection of images and short video clips in response to questions from farmers about their crops. The officer would like farmers to be able to rate and comment on the items in the collection.

Circle the ICT tool(s) from that are a good fit for this purpose

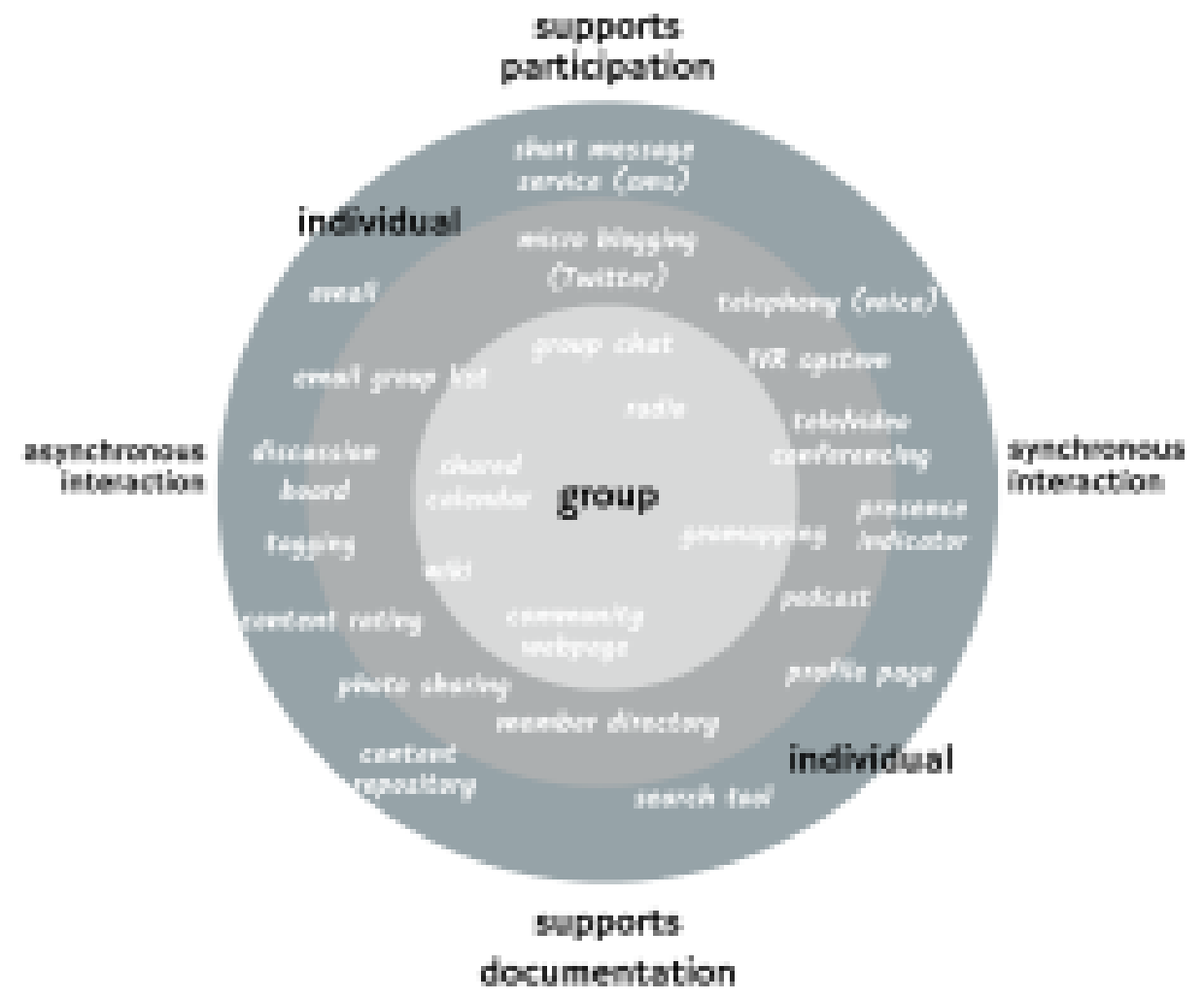

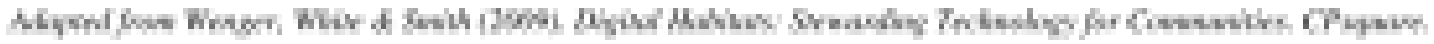

Can you think of a platform or app that includes this tool(s)? Write it down here: 
Worksheet 1.3: Choosing an ICT Tool | 16 


\section{Worksheet I.4: Planning and Managing a Campaign}

Download PDF (1.4 Planning and Managing a Campaign)

A well-defined campaign goal includes three important details. Complete these sentences based on the details in Part D of the case study:

The specific target of the campaign was to:

The specific activity of the campaign was:

The community of practice involved in this campaign was:

Review Case Study PART F

Discuss these questions with your group and write down your answers.

1.) What key factor influenced the decision on when the campaign would take place? How long did the campaign run?

2.) What other kinds of factors might influence the timing or duration of a campaign?

3.) The case study describes some of the activities of the Tech Steward prior to the launch of the campaign. What were they?

17 | Worksheet 1.4: Planning and Managing a Campaign 
4.) In this case, did the Tech Steward or the community require any special training, administrative approval, or financial support to set up the technology for the campaign?

5.) Imagine the details of the case were different. Can you suggest an example of a choice of ICT tool or platform that would require special training, administrative approval, or financial support?

6.) The case study describes some of the activities of the Tech Steward at the end of the campaign. What were they?

7.) How did the Tech Steward collect information to assess whether the campaign had met its objective?

- Before the campaign:

- During the campaign: 
- After the campaign:

8.) Based on the Results and Conclusion section of the case study, what impact did the Tech Steward and the campaign have on this community of practice?

19 | Worksheet 1.4: Planning and Managing a Campaign 


\section{SESSION 2: ENGAGING YOUR COMMUNITY AND CREATING A CAMPAIGN}

WORKSHEETS

2.1: Identify a Community of Practice

2.2: The Technology Steward

2.3: Community Characteristics

2.4: Community Consultation

2.5: Establishing the Campaign Goal

2.6: Create a Use-Case Scenario 


\section{Worksheet 2.I: Identify a Community of Practice}

The Tech Stewardship approach focuses its efforts on communities of practice as the unit of engagement and transformation. Leadership and social influence are important factors in changing practices related to ICT choice.

Communities of practice are groups of people who share a concern, a set of problems, or a passion about a topic, and who deepen their knowledge and expertise in this area by interacting on an ongoing basis.

-Wenger E., R. McDermott, W. Snyder (2002). Cultivating Communities of Practice. Harvard Business Press. (p.4)

You are likely a member of a community of practice but may have never thought about it before.

Consider the statements in the following table. To what extent do they reflect your interactions with others in your field? Can you identify a community of practice to which you belong?

If you can't identify an existing COP, can you imagine a community of practice that might be created to serve your professional development and/or business interests?

Download PDF worksheet (2.1 Identify a Community of Practice) 


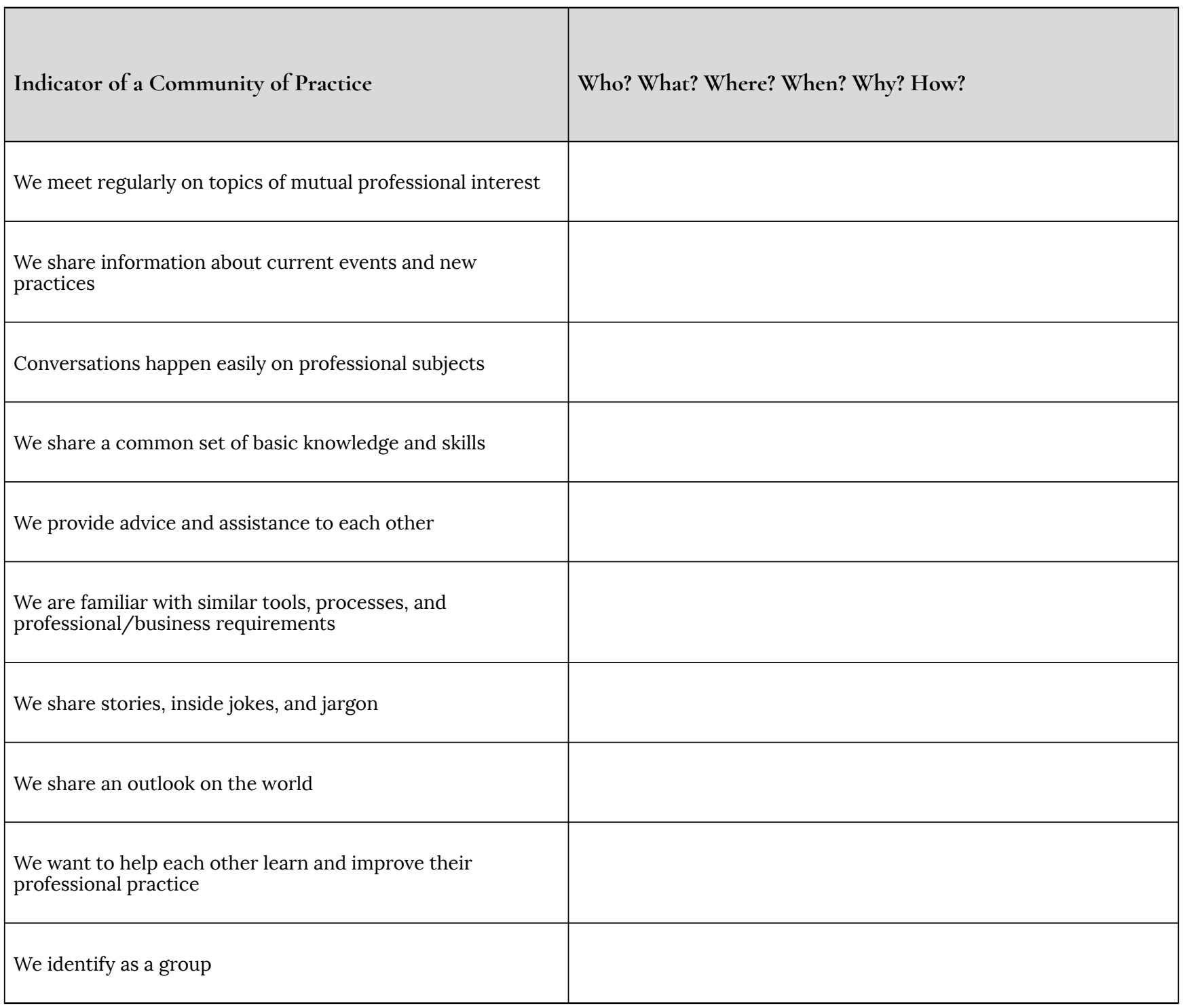

Share and discuss with your partner, then discuss as a group. List the communities of practice that you have identified with your group:

To what extent is ICT being used by or within these communities of practice? Is it effective? Is it being used to its full potential?

Choose a community of practice with your group members, give it a name, and write it down here with a brief description of its "shared concerns [and] passion about a topic": 


\section{Worksheet 2.2: The Technology Steward}

Tech stewards most often are members of the community they serve. They just happen to pay attention to technology issues in the community's life.

-Wenger, E., N. White, J. Smith (2008). Digital Habitats: Stewarding Technology for Communities. CP Square. (p.25)

Technology Stewardship is a community leadership role. People take on the role for several reasons (often more than one):

- No one else is doing it

- Satisfaction in serving the needs of the community of practice

- Establishing and helping to realize a vision for the community

- Personal learning and growth

- Professional development and advancement

The Tech Steward role is typically part-time and voluntary. In some cases, it is an ad hoc response to address a specific problem or opportunity. Other times it is a longer-term and strategic commitment on the part of the community.

The demands of the role vary by community and by situation. Technology Stewardship can take on many different possibilities. No one size fits all.

There are five primary streams of activity in the Tech Steward role:

- Understanding the community, its needs, and its aspirations

- Be aware of ICT choices and developments of interest to the community

- Help the community make informed choices about ICT tools and platforms

- Help the community experiment with ICT choices

- Help the community to integrate effective ICT choices into everyday use

This course has been designed to introduce the Technology Stewardship approach. Some participants will see themselves as doing tech stewardship already, and this course may help them to improve their practice.

Others will see it as a role they could fulfil to help serve the interests of their community.

Those participants not interested in serving as tech stewards can still benefit from understanding the role and telling others about this approach.

Take a moment to review the questions in the following table and then discuss with your group members. 


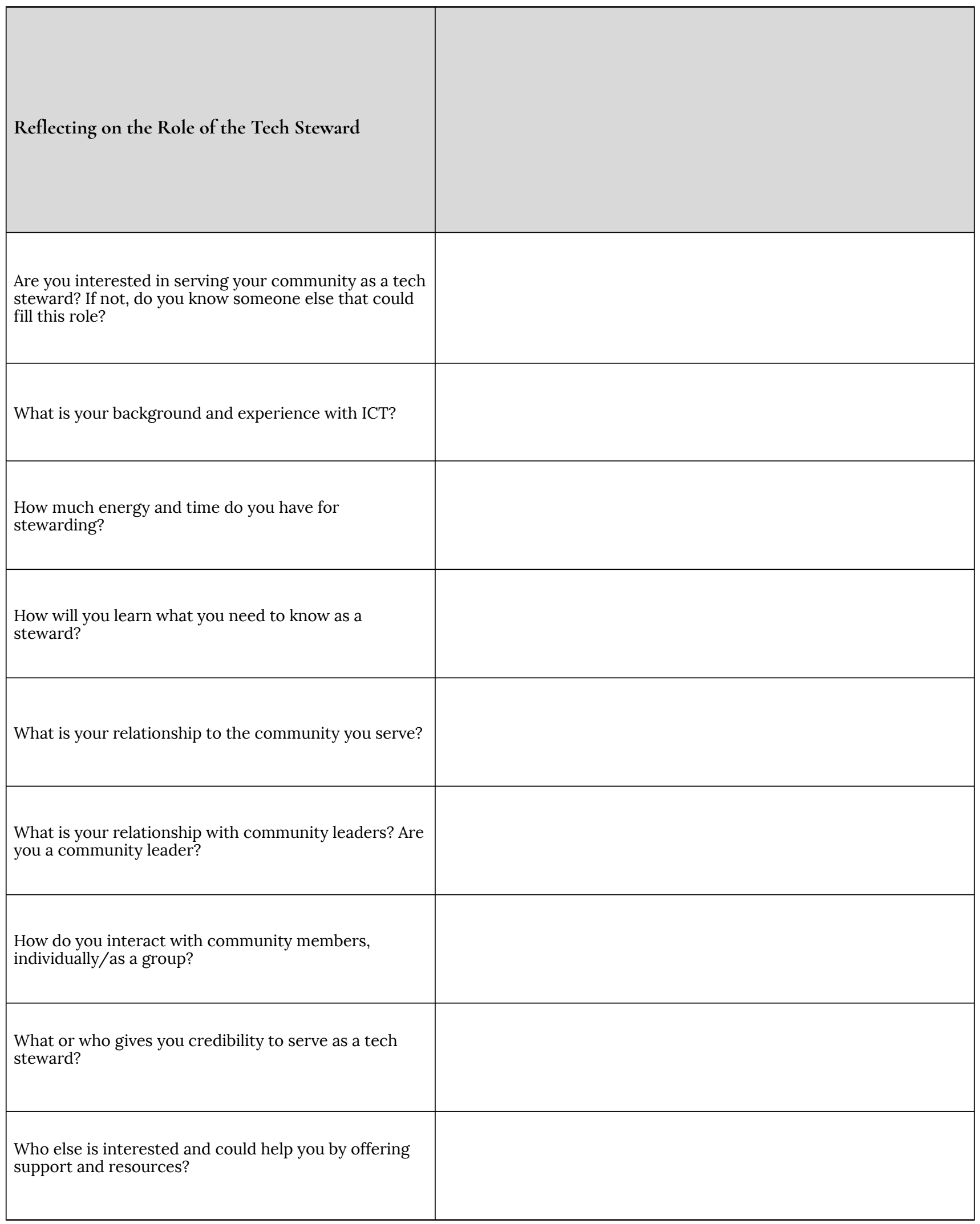


How do your responses to these questions compare with those of your group members? Do you have a Tech Steward in the group? Do you have potential Tech Steward in the group?

Write down some key points and questions from your discussion to share with the class.

25 | Worksheet 2.2: The Technology Steward 


\section{Worksheet 2.3: Community Characteristics}

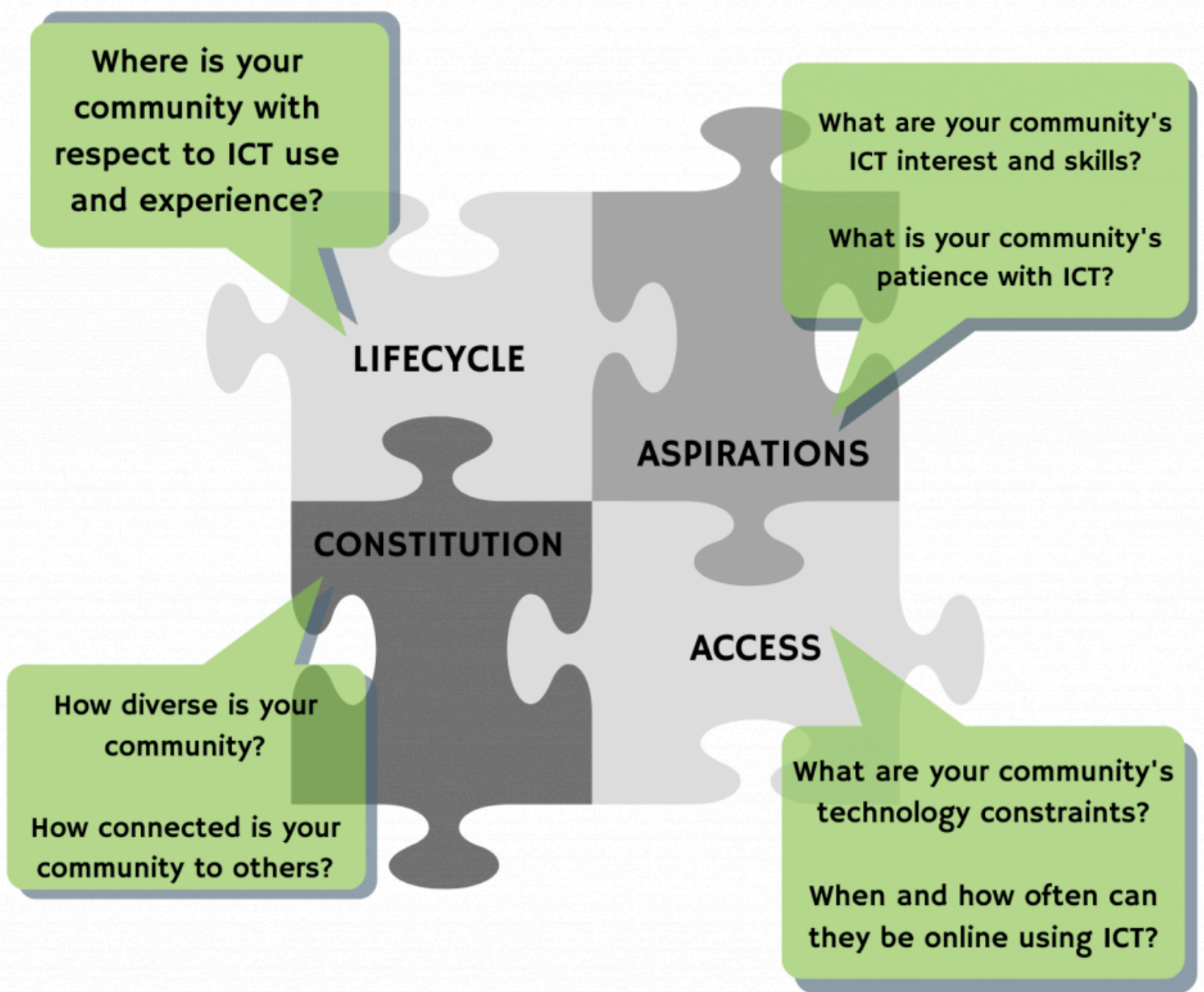

Download PDF (2.3 Community Characteristics)

LIFECYCLE: Where is your community with respect to its stage of maturity?

, Just forming: we need basic tools to connect as a community

, Self-designing: we have a strong sense of what we want to accomplish as a community of practice but haven't got there yet

, Growing and restless: we have some accomplishments behind us and are ready to try something new with the community

Stable and adaptive: we are satisfied with what we are doing now but willing to try new ideas if they provide benefits 
CONSTITUTION: How Diverse is your Community?

What are the different types of members and what are their levels of participation in the community?

How spread apart is the community in terms of location and time zones?

\begin{tabular}{llll}
\hline No Spread & & Widespread & 5 \\
\hline 1 & 2 & 3 & 4 \\
\hline
\end{tabular}

Comments:

What language(s) do members speak?

Comments:

How would you rank gender, age, or other cultural diversity among the community membership?

Comments: 


\section{How connected is your community to other communities?}

How much do you want to control boundaries of the community? Do you want the community interactions:

- , To be private and secure?

- , To be open and shared widely?

- , For some to be private and some to be public?

Do you need ICT tools or platforms in common with other communities?

- , Yes

- , No

- , Not sure

Does your community have (or need) support for ICT use from an oversight organization or government department?

- Yes

- , No

- , Not sure

Based on the answers to the last three questions, how would you rank your community in terms of its level of independence when choosing ICT tools/platforms:

Comments:

Add up the score from the rankings in the CONSITUTION section:

Score of 15-20 suggests a community with high level of diversity and dependence within an organizational context or tight linkages to other communities. The choice of ICT will need to strike a balance between accommodating different user needs and preferences, while providing the ability to integrate with other ICT tools and platforms.

Score of 5-10 suggests a community that has a low level of diversity and is relatively independent of organizational 
context with few or no dependence on other communities. The choice of ICT is flexible but will need to find consensus within the community to arrive at an optimal solution. However, future integration with other communities and ICT systems may be problematic.

Score of 10-15 is in the middle range and suggest the need to choose ICT tool/platform that provides some flexibility for community members and is capable of integration with other systems.

ASPIRATIONS: What are your community's ICT interests and skills?

How interested are your community members in using or trying ICT tools and platforms?

Comments:

What is their capacity for learning new ICT tools and practices?

Low Capacity

1

Comments:

What is the average current level of ICT-related skills among community members? 
Comments:

Is there a probability of conflict in the community when introducing new ICT practices?

Comments:

How many ICT barriers are members willing to cross to use a new ICT platform? (e.g., need to create new accounts and passwords, need to download new apps)

Comments: 
Add up the score from the rankings in the ASPIRATIONS section:

Score of 18-25 suggests a community with a high level of tolerance for experimentation with new ICT choices; however, with this enthusiasm comes strong opinions that could lead to potential conflict. The choice of ICT can be ambitious but the Tech Steward will want to provide lots of opportunities for constructive feedback from community members during the campaign to help diffuse points of conflict.

Score of 5-12 suggests a community that has a low level of tolerance for experimentation with new ICT choices. The choice of ICT should be modest and address an immediate need for the community. The Tech Steward should start with a short and simple campaign using existing ICT as a way of introducing community members to a new practice. If the potential for conflict is high, the Tech Steward will want to provide lots of opportunities for constructive feedback from community members during and after the campaign to help diffuse points of conflict.

Score of 12-18 is in the middle range and suggest a community that is willing to experiment with modest new ICT choices. The Tech Steward should start with a short and simple campaign but look for opportunities to introduce more advanced practices if the community members seem interested. Be careful not to overwhelm community members by making too many demands on their practice. Be aware of potential points of conflict within the community and work to mitigate them by providing members with opportunities to provide feedback and voice concerns.

\section{ACCESS: What are your community's technological constraints?}

What ICT devices do members have access to on a regular basis?

- , Basic mobile phone

- , Smartphone

- , Tablet computer

- , Desktop computer with Internet

- , Desktop computer without Internet

- , Laptop computer with internet

- , Laptop computer without internet

- , Telecentre or cybercafé with computers and Internet

- , Radio

- , TV

- , Other:

- , Other:

- , Other:

What level of internet access is available to most members of the community? 


\section{Comments:}

What financial constraints might affect ICT use by community members? Do they use pre-paid accounts for their ICT devices and/or Internet access? Do they share or pool resources to pay for internet service?

How much time/when are most members able to be online and using ICT?

- , Never

- , Once a week

- , Several times a week

- , Daily

- , Anytime/always

The Tech Steward should help the community to choose ICT tools/platforms that are suited to the local access conditions and constraints. Consider these elements when designing the campaign and the campaign evaluation plan. Consider the cost implications of using the ICT tool. Consider how the ICT tool and internet access fits into the daily routine of the community members.

Check the boxes in the diagram below to create a profile of your community of practice. 


\section{Worksheet 2.4: Community Consultation}

Following the principle Vision before Technology, the Tech Steward consults with the community members to discuss challenges and opportunities that ICT might be able to address.

Not all problems will be suited to an ICT solution but sometimes this will only be discovered during or after a campaign.

There are various participatory methods for community consulting and you may have experience with some already. The Problem/Opportunity Tree is a method we use in this course.

\section{4(a) Problem Tree Exercise}

Begin at the trunk: what is a problem that our community of practice is facing right now? Write down a list of problems if there is more than one that comes to mind.

\section{Problem Tree}

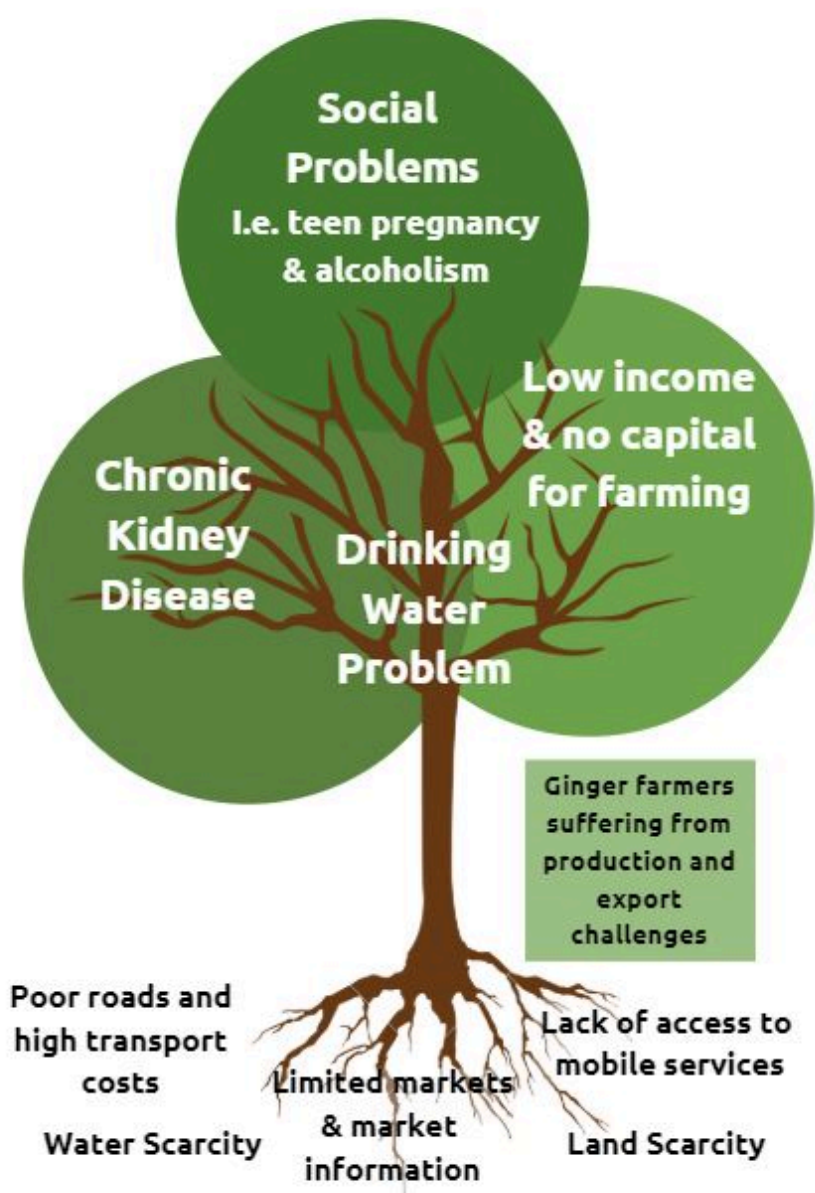

Effects

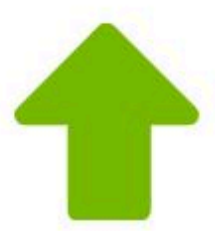

Problem

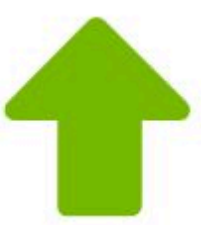

Causes 
Go to the roots: what are the causes, situations, factors that have led to the problem? Why does the problem exist? There may be more than one cause.

Then go to the branches: what are the effects created by the problem? How do we experience the problem in our daily routines, practices, or group processes?

\section{4(b) Opportunity Tree Exercise}

Having identified the problem, the causes, and effects, we then consider the opportunities available to the community for making changes.

Start with the branches: What is our vision for the future? What outcome do we want to experience in our daily routines, practices, and group processes?

\section{Opportunity Tree}

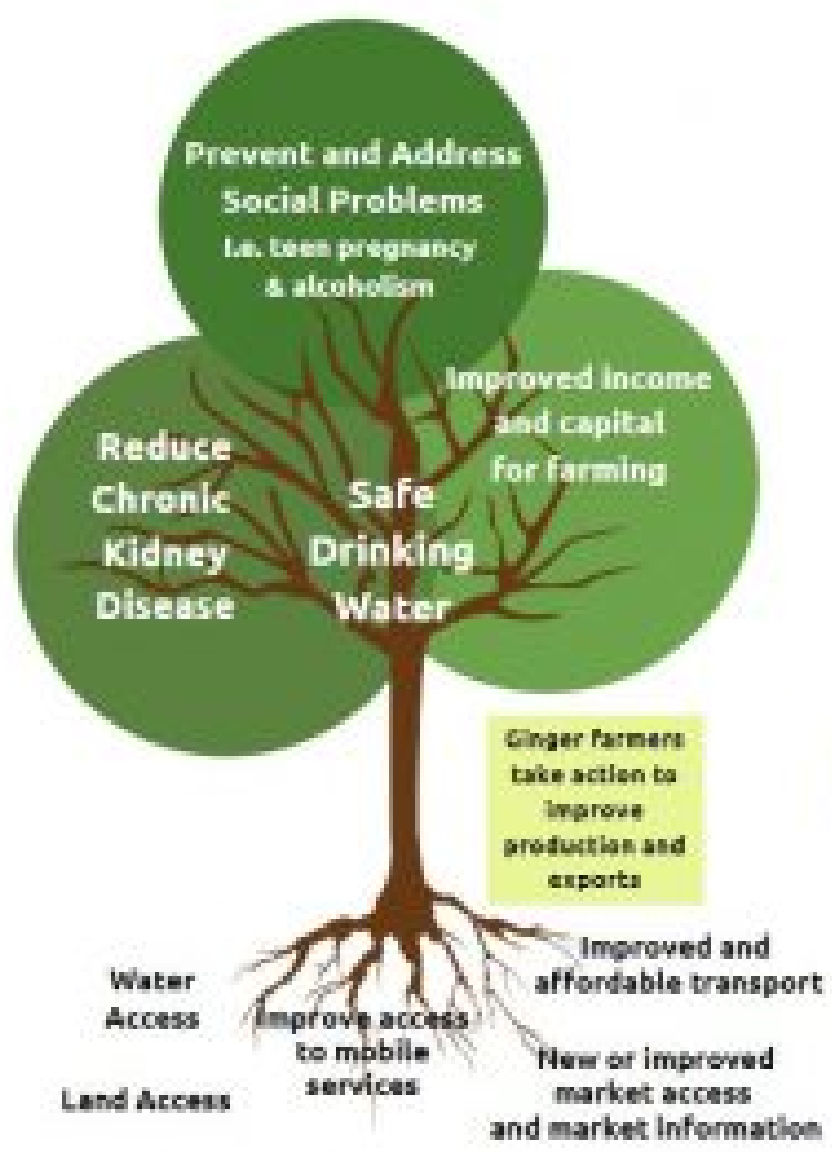

\section{EFfects}

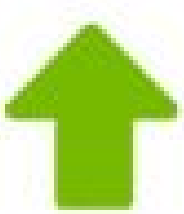

Problem

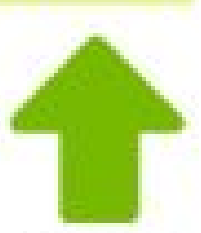

Causes

Go to the roots: What actions, changes in practice, routine, or situation will need to take place to help us achieve our objective? What role can ICT play in helping us to achieve the objective? 
Go to the trunk: How do we restate the problem in a positive way? What is the objective and outcome we are trying to achieve with a change in practices and routines? 


\section{Worksheet 2.5: Establishing the Campaign Goal}

Review the Opportunity Tree exercise and what you wrote down for the Roots (means) needed to address the problem.

The following ranking table will help us understand how to act by translating means into communication actions for the community of practice.

\section{5(a) Translate Means into Action}

Download PDF (2.5 a Translating Means into Action)

Rank each type of action from 1 to 5 ( 5 being most relevant or important) based on the list of means identified in the Opportunity Tree exercise. 


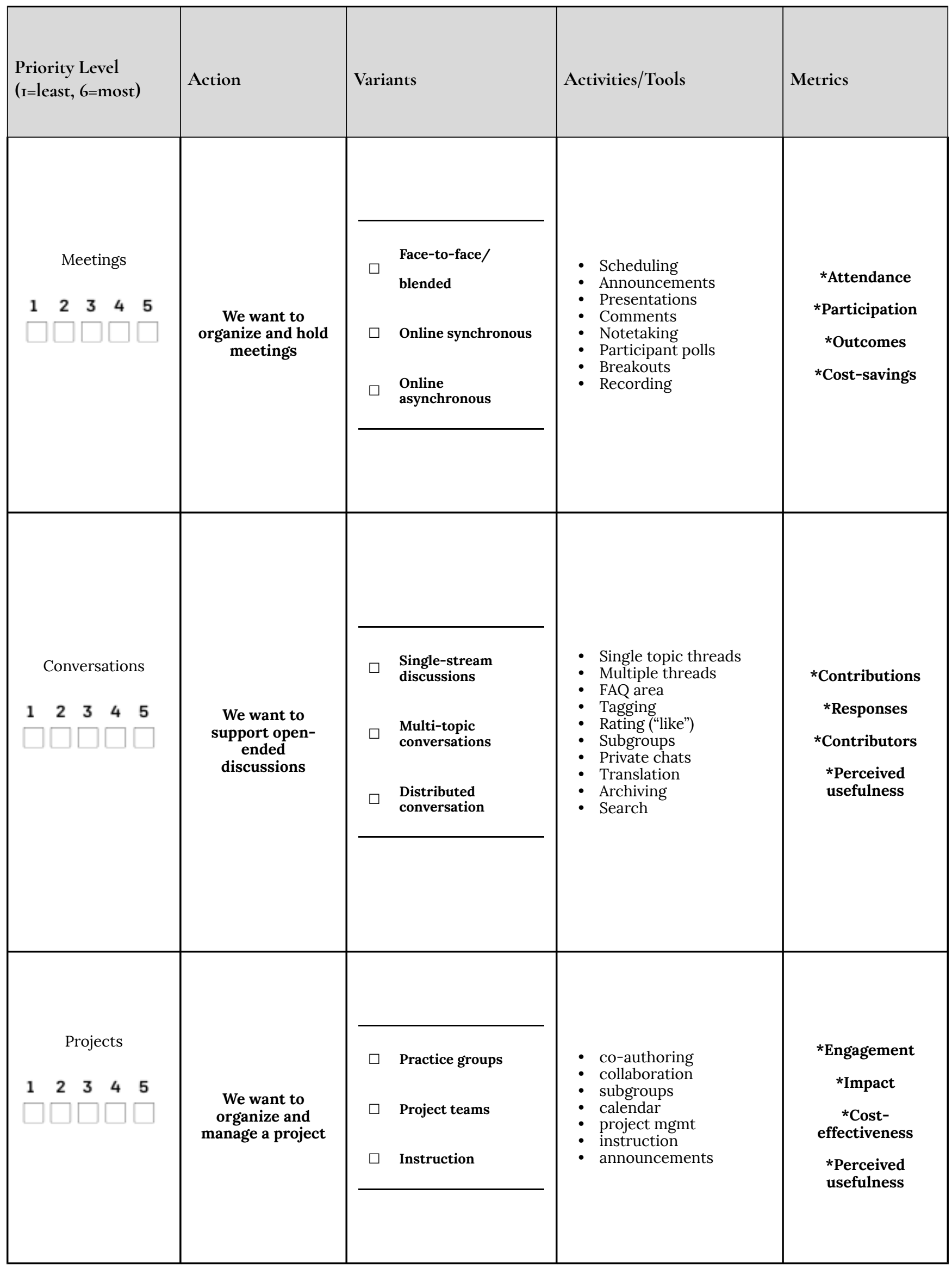




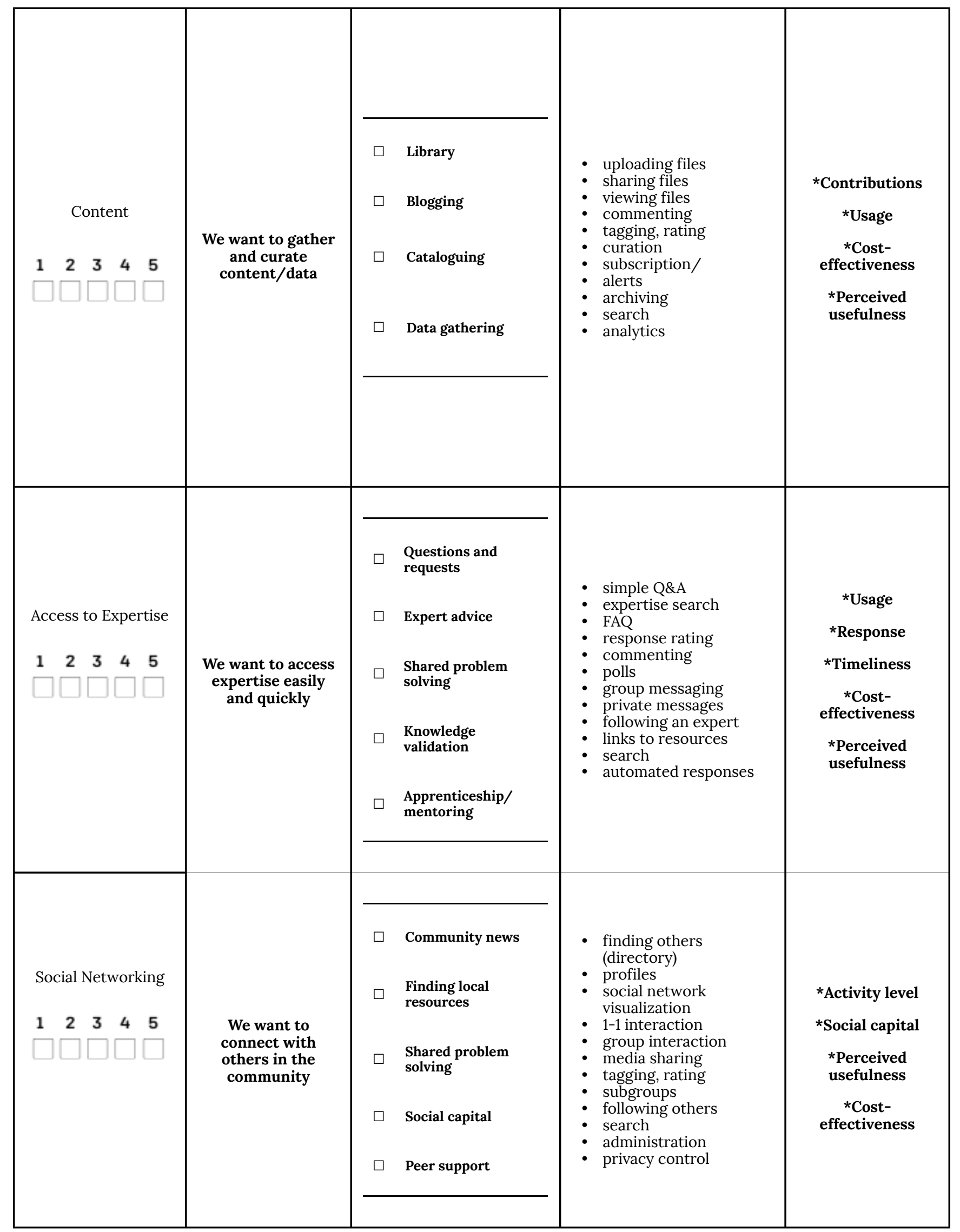


Download PDF (2.5 b Identify a Priority for the Campaign)

A Spider Diagram can then be used to help visualize the priority actions that will contribute to the desired outcome. You can use the diagram multiple times to monitor and evaluate changes over time.

This exercise is best performed as part of the community consultation.

Plot the ranking of each action on the diagram and then draw a line between the points to form an outline of a web.

The action with the highest priority should be the focus for your first campaign.

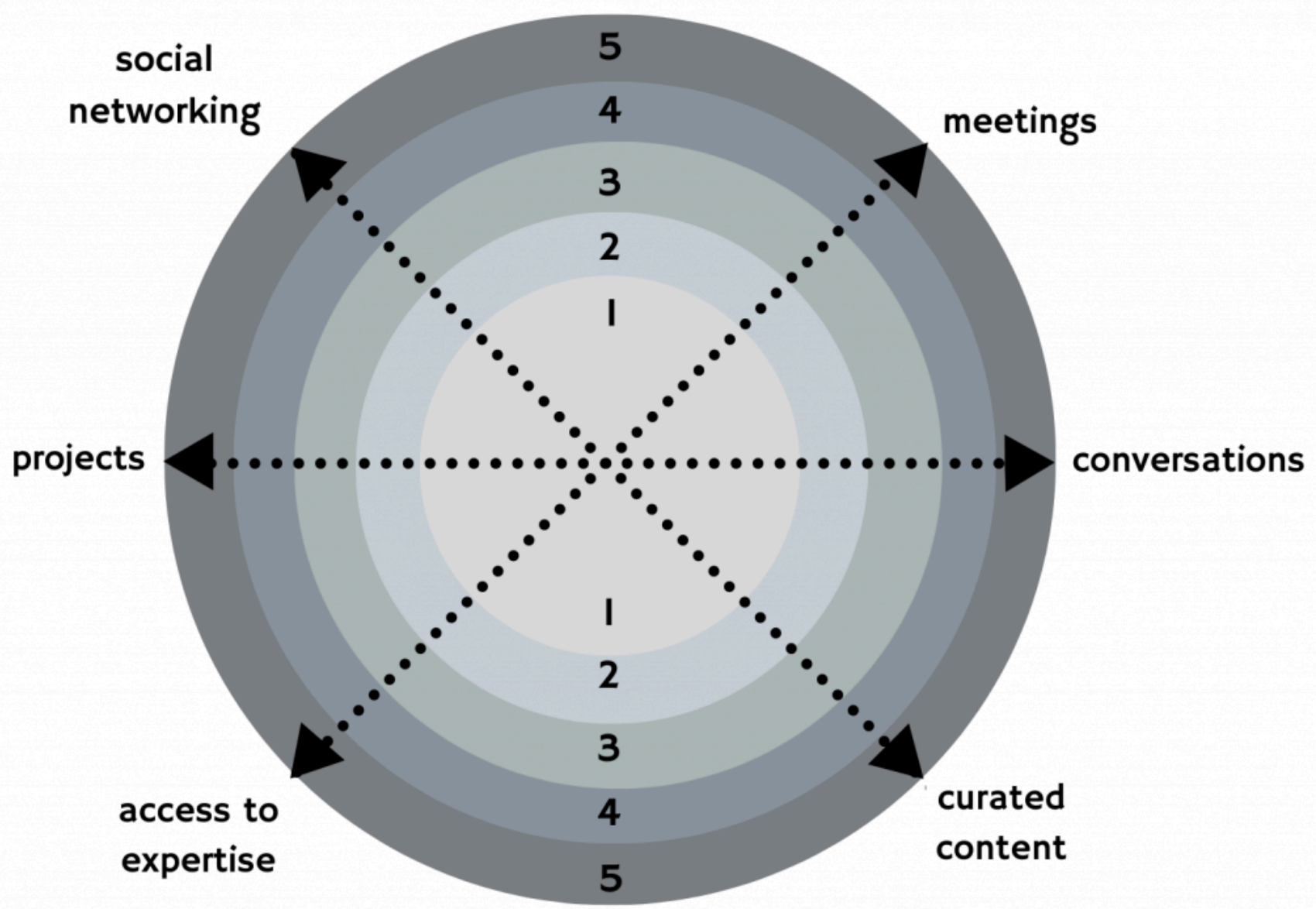

Adapted from Wenger, White \& Smith (2009). Digital Habitats: Stewarding Technology for Communities. CPsquare.

\section{5(c) Establish a Campaign Goal}

The next step is to establish a goal for the campaign. As mentioned in Part D of the Case Study, a well-defined goal contains three important details:

- it sets a specific objective;

- for a specific action;

- with a clearly defined community of practice;

39 | Worksheet 2.5: Establishing the Campaign Goal 
We can use the results of the Opportunity Tree exercise and Spider Diagram to help write the campaign goal:

The goal of the campaign is to

[objective from the Opportunity Tree]

by using ICT to

[priority action from the Spider Diagram]

for

[your community of practice]. 


\section{Worksheet 2.6: Create a Use-Case Scenario}

A use-case scenario describes a set of ICT-related activities that support the priority action and campaign goal. It identifies different actors who would use the system and different functional requirements of an ICT tool. This helps the Tech Steward to choose an appropriate ICT tool for the campaign.

There are four important parts in a use-case scenario:

1. Actors: the people who use the system (e.g. Farmers, agriculture instructors, input suppliers). There are four types of actors:

- active users (those who initiate activities)

- passive users (those who receive information but do not initiate an action)

- administrators (those who manage and control access to the ICT platform)

- ICT tools (when they perform programmed responses or functions)

2. Activities: The actions performed by actors (e.g. send meeting schedule, request information or ask questions)

3. Sequencing: The order in which activities happen when a user interacts with a system

4. Value/Outcome: The intended value or process improvement created by performing the task as described in the campaign goal:

- "Improve timeliness and reduce costs of communicating with farmers in the community."

The use-case scenario should be imagined from a user's point of view. It describes in simple language who is involved and what activities take place in relation to the campaign orientation.

\section{6(a) Develop your Use-Case Scenario}

- On one set of cards or Post-it Notes (provided by your facilitator), list the main 'actors' (users and administrators) that will be involved in the campaign;

- On another set of cards or Post-it Notes (provided by your facilitator), list the ICT-related activities these actors will be doing during the campaign;

- Arrange your cards/Post-it Notes to show the sequence of activities. Use this arrangement to draw a simple UseCase diagram showing the actors and the activities that you expect to take place during the campaign.

\section{Example of a Use-Case Diagram}

This picture is an example of a simple use-case diagram based on the case study:

Based on the information presented in the diagram we can then create a list of actors and activities for the campaign. (Additional activities were added to the list after reviewing the diagram.) 


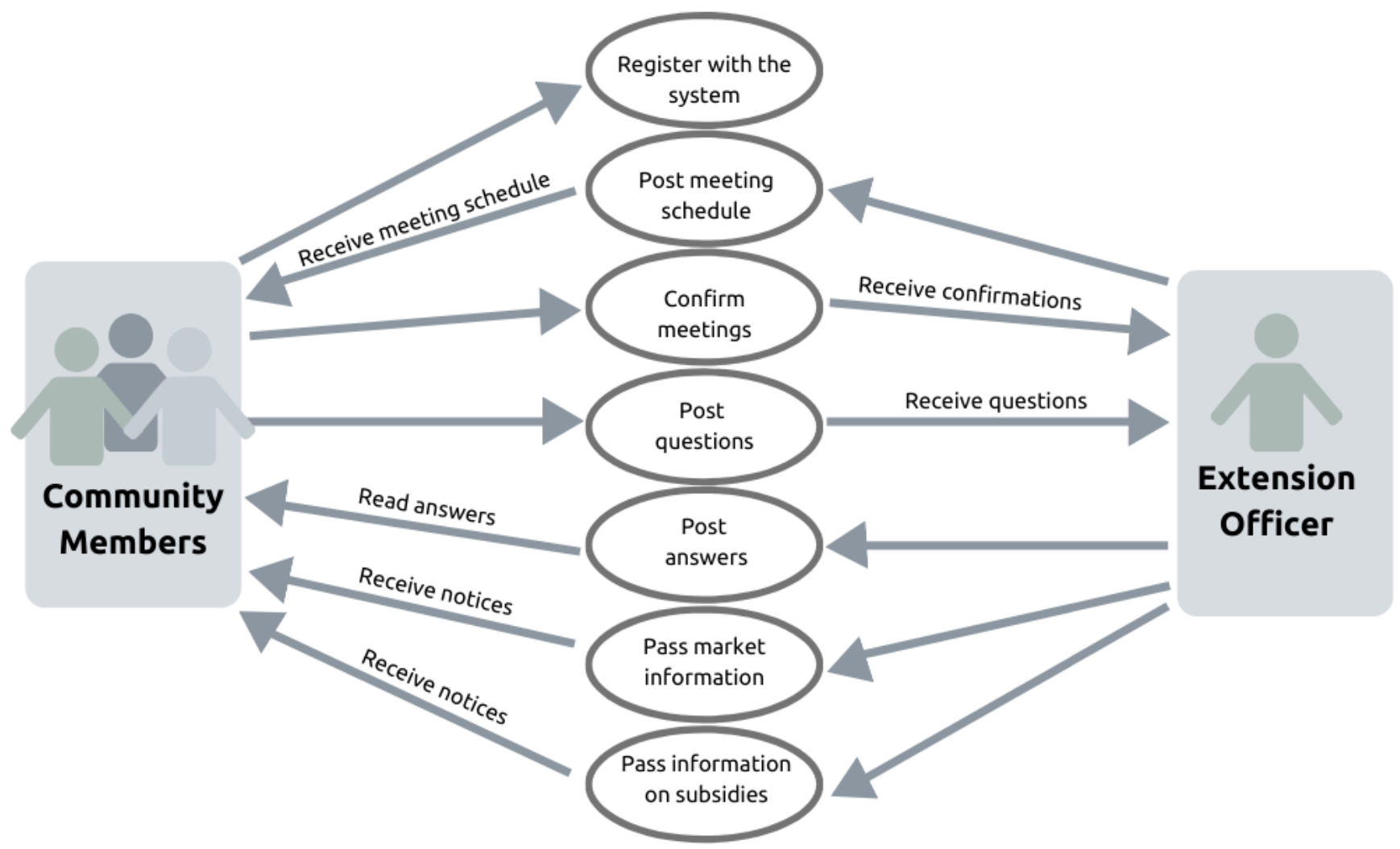

\begin{tabular}{|c|c|}
\hline Actors & Activities \\
\hline $\begin{array}{l}\text { Community members } \\
\text { (Farmers) }\end{array}$ & $\begin{array}{l}\text { Register with the system (join the group chat) } \\
\text { Receive meeting schedule } \\
\text { Confirm attendance at meetings }\end{array}$ \\
\hline $\begin{array}{l}\text { Technology Steward } \\
\text { (Extension officer) }\end{array}$ & $\begin{array}{l}\text { Create a group chat } \\
\text { Send a welcome note to new members of the group } \\
\text { Post schedules of meetings } \\
\text { Post reminders of upcoming meetings } \\
\text { Share information and important updates }\end{array}$ \\
\hline & $\ldots$. \\
\hline
\end{tabular}

\section{6(b) Draw your Use-Case Diagram:}

Download PDF (2.6 Use-Case Diagram Worksheet) 


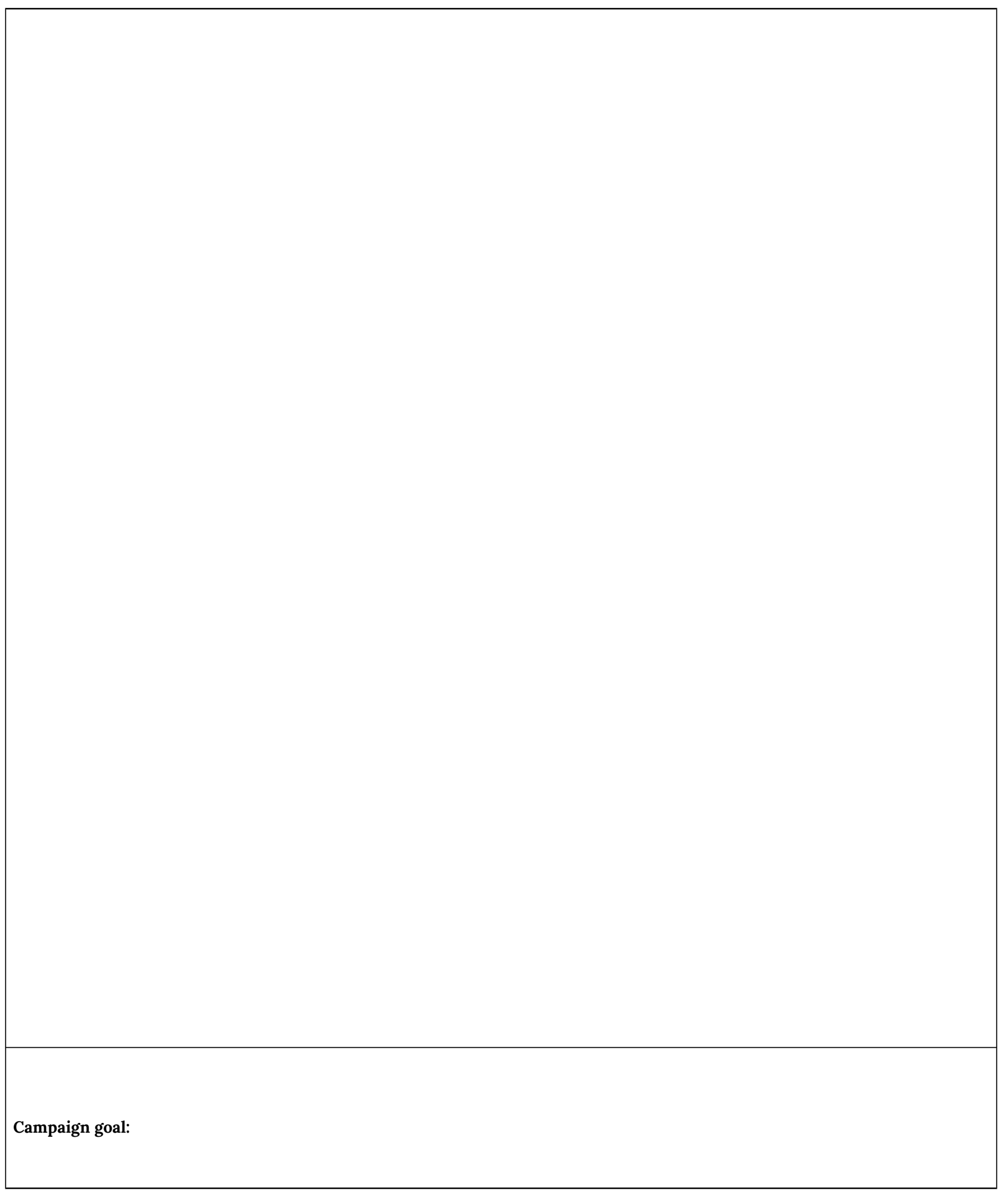

2.6(c) List the Actors and Activities from the Use-Case Diagram:

43 | Worksheet 2.6: Create a Use-Case Scenario 
Review your diagram carefully and discuss it with your group. Have you identified all the important actors? Have you identified all the important activities?

When you are satisfied that the diagram is reasonably complete, then list the actors and activities in the table below. The table will be used in the next session to help you generate a list of ICT tools for the campaign.

Download PDF worksheet (2.6 c Actors and Activities)

\begin{tabular}{|l|l|}
\hline Actors & Activities \\
\hline & $\cdot$ \\
\hline & $\cdot$ \\
\hline
\end{tabular}




\section{SESSION 3: CHOOSING AN ICT PLATFORM AND RAPID PROTOTYPING}

\section{WORKSHEETS}

3.1: Matching Activities with ICT Tools

3.2: Choosing an Acquisition Strategy

3.3: Identify your ICT Platforms

3.4: Match the Tool(s) with a Platform

3.5: Evaluate the Platform

3.6: Prepare and Test the Prototype 


\section{Worksheet 3.I: Matching Activities with ICT Tools}

Refer to your Use-Case Diagram from Session 2 to write down the campaign goal you created in the previous session:

Now use the Tools Landscape graph to circle all of the tools that can support the activities that were identified in your use case scenario. You can add tools that aren't on the graph if necessary.

In the following table, list the activities from your use case scenario in the previous session. Then match each activity with a tool(s) you circled in the Tools Landscape Graph. Note any features that they will need to support.

Download PDF worksheet (3.1 Matching Activities with Tools)

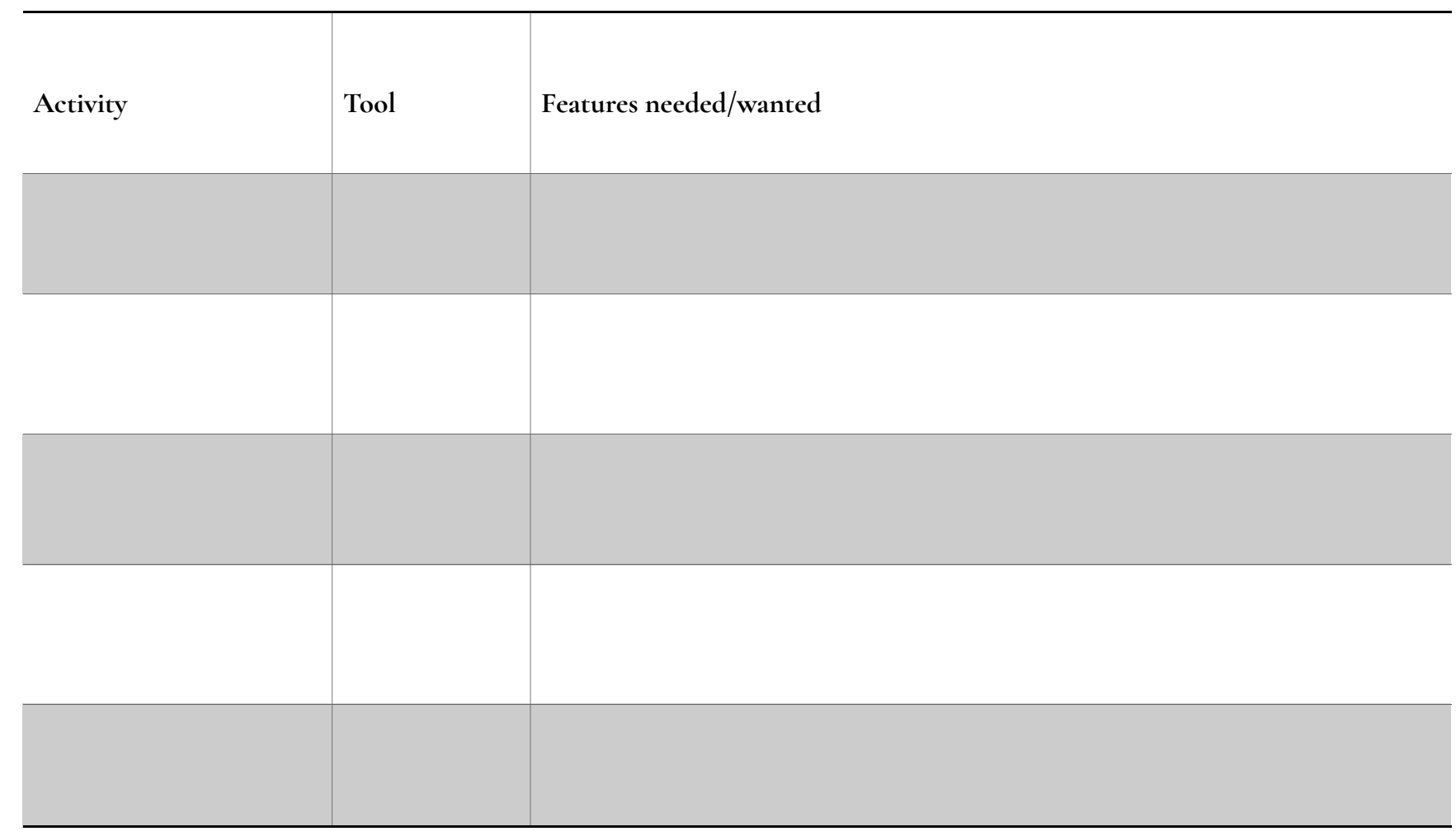




\section{Worksheet 3.2: Choosing an Acquisition Strategy}

Begin by first considering the most appropriate acquisition strategy for the campaign.

Be mindful that the campaign serves as a 'pilot' and might be the first step toward more advanced ICT tools and platforms for your community, so stick with the guiding principle: keep it simple.

Download PDF (3.2 Choosing an Acquisition Strategy)

\begin{tabular}{|l|l|}
\hline $\begin{array}{l}\text { Do you want to get up and running quickly but aren't ready or } \\
\text { able to invest in an ICT platform yet? }\end{array}$ & Strategy I: Use what you have \\
\hline What are community members already using in their daily lives? & \\
\hline $\begin{array}{l}\text { Can you repurpose an existing platform or make small adjustments } \\
\text { for the campaign? }\end{array}$ & \\
\hline $\begin{array}{l}\text { Are their skill gaps in the community that prevent an existing ICT } \\
\text { platform from supporting the campaign? }\end{array}$ & \\
\hline $\begin{array}{l}\text { Will the campaign add costs to your community members when } \\
\text { using of this platform? }\end{array}$ & \\
\hline
\end{tabular}


Do you need an ICT tool or features that aren't already available to the community but requires no money?

Is the platform accessible to everyone that needs it?

Can you live with advertisements on it?

How important is control of your community data?

How much work is involved in configuring and using this tool?

Can the platform grow with usage?

Are there any hidden costs?
Strategy 2: Choose a free platform

\begin{tabular}{|l|l|}
\hline How much work is involved in configuring and using this tool? & \\
\hline Can the platform grow with usage? & \\
\hline Are there any hidden costs? & \\
\hline
\end{tabular}

Does your community of practice have access to resources to pay for a commercial platform?

Will the platform be accessible to everyone that needs it?

Do you need all the tools and features it provides?

Is the platform suited to your primary orientation and community focus?

How much work is involved in configuring and using this platform?

How easily can the platform integrate with existing ICT tools and platforms in the community?

Are there any hidden costs?
Strategy 3: Get a commercial platform/upgrade from free 
Do you have unique needs that aren't well-served by any single platform? Are you not interested in or ready for a custom-designed platform?

Do you have more than one ICT tool that you need to integrate into an activity?

Do you have resources, time, and skills necessary to experiment with an unfamiliar platform?

How much work is involved in configuring and using this platform?

How easily can the platform integrate with existing ICT tools and platforms in the community?

What support is available to assist with this platform?

How much does it cost?
Strategy 4: Patch pieces together 
Do you have unique needs not met by existing platforms? Do you have deep technical knowledge and support in your community? Do you have a developer?

Are you sure you are ready for this?

Have already you conducted a campaign with a free/low-cost platform first?

Have you clearly defined the technological functionality, features, and back end support required?

Have you clearly identified the administrative and security considerations?

How willing is your community interested or willing to try something new and unfamiliar?

What are your long term plans to support a custom-designed platform?
Strategy 5: Build your own/hire a developer 


\section{Worksheet 3.3: Identify your ICT Platforms}

Once you have decided on a technology acquisition strategy, the next step is to identify the range of choices available within that category. ICT platforms are constantly changing, with new ones appearing frequently and other disappearing from the market.

Working with your group members, complete the sections of table that include some of the more common ICT platforms.

\section{Strategy 1: Use What You Have}

Download PDF (3.3 Strategy 1 Use What You Have) 


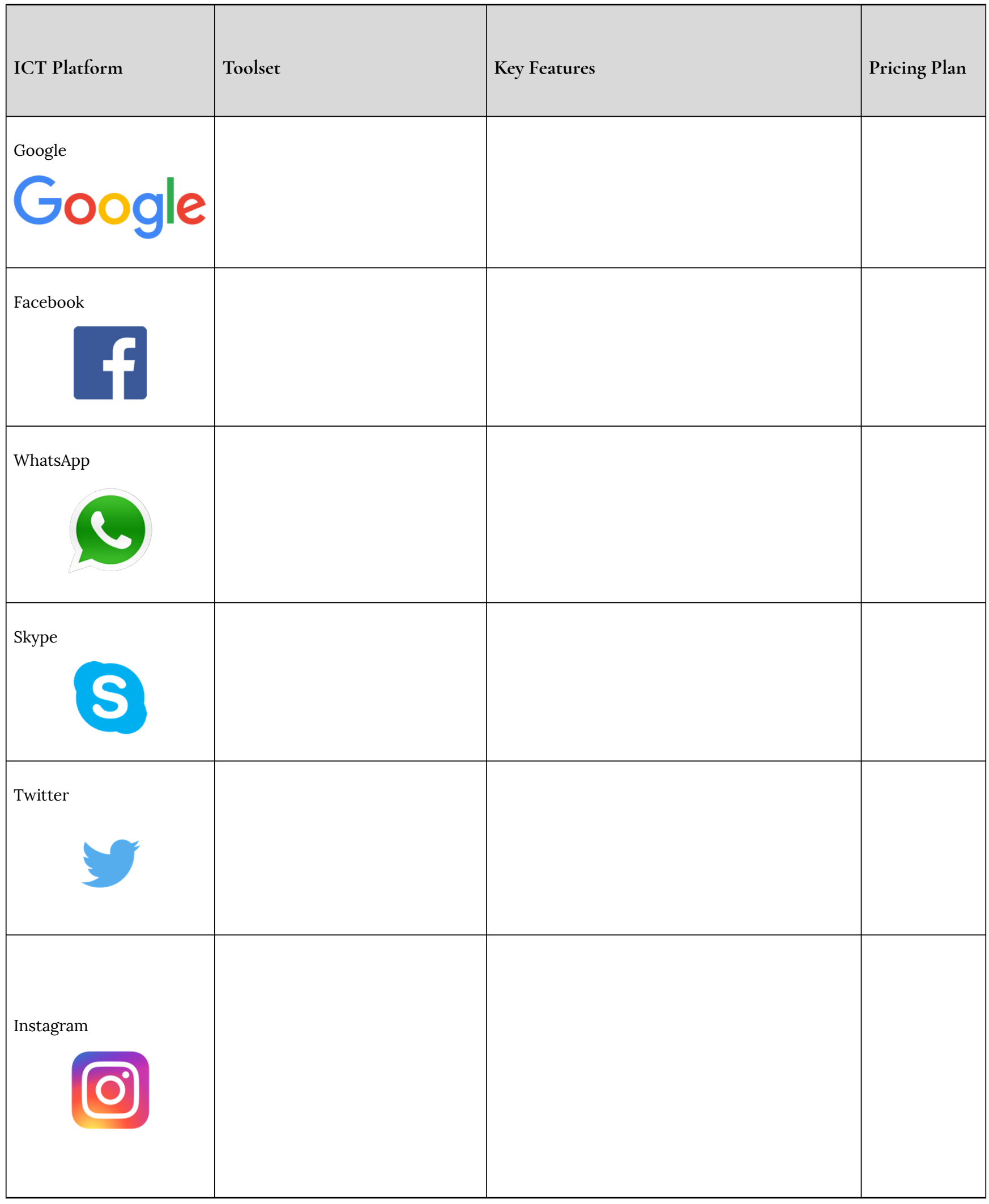

\section{Strategy 2: Choose a Free Platform}

Download PDF (3.3 Strategy 2 Choose a Free Platform) 


\begin{tabular}{|c|c|c|c|}
\hline ICT Platform & Toolset & Key Features & Pricing Plan \\
\hline mFisheries & $\begin{array}{ll}\text { - geomapping } \\
\text { - SMS } \\
\text { - photo-sharing } \\
\text { - } \text { pontent repository }\end{array}$ & $\begin{array}{l}\text { - Android app (currently listed as } \\
\text { - } \quad \text { suite of tools ('modules') for small scale } \\
\text { fishers } \\
\text { - SOS communications with GPS data } \\
\text { through SMS } \\
\text { - at-sea tracking and logging } \\
\text { - } \text { alert notification by user group } \\
\text { - } \text { weather updates } \\
\text { - camera tool } \\
\text { - } \quad \text { last update Jan. } 2018\end{array}$ & Free \\
\hline $\begin{array}{r}\text { Namdevco-SMS } \\
\text { namde }\end{array}$ & - $\mathrm{SMS}$ & $\begin{array}{l}\text { - Any mobile phone } \\
\text { price notification by commodity using } \\
\text { keyword } \\
\text { user pays SMS charge for receiving } \\
\text { messages }\end{array}$ & Free \\
\hline AgriMaps & $\begin{array}{l}\text { - } \text { geomapping } \\
\text { content repository }\end{array}$ & $\begin{array}{l}\text { - } \text { Android app } \\
\text { - } \text { GPS-based mapping feature } \\
\text { - } \text { land profile and crop recommendation } \\
\text { - last update July } 2016\end{array}$ & Free \\
\hline AgriPrice & $\begin{array}{l}\text { - } \text { content repository } \\
\text { notification }\end{array}$ & $\begin{array}{l}\text { - } \text { Android app } \\
\text { - } \text { price tracking of crops } \\
\text { - last update July in required for notifications }\end{array}$ & Free \\
\hline AgriExpense & $\begin{array}{ll}\text { - } & \text { database } \\
\text { - } & \text { calculator }\end{array}$ & $\begin{array}{l}\text { - Android app } \\
\text { - } \text { online data backup } \\
\text { - } \text { multiple device sync } \\
\text { - last update Apr. } 2017\end{array}$ & Free \\
\hline CABI Plantwise & $\begin{array}{l}\text { - } \text { content repository } \\
\text { - } \text { search tool }\end{array}$ & $\begin{array}{l}\text { - Android app } \\
\text { - on-demand factsheets } \\
\text { - } \text { 'prowse by crop, by problem, by country } \\
\text { problems' } \\
\text { - } \text { expert information } \\
\text { - last update Jan. } 6,2018\end{array}$ & Free \\
\hline
\end{tabular}




\begin{tabular}{|c|c|c|c|}
\hline SR-Market & $\begin{array}{l}\text { - } \text { member directory } \\
\text { - } \text { search tool } \\
\text { - } \text { notifification }\end{array}$ & $\begin{array}{l}\text { - Android app } \\
\text { virtual market/forum for the small } \\
\text { ruminants industry } \\
\text { interaction takes place externally from the } \\
\text { app } \\
\text { - last update Oct. } 2016\end{array}$ & Free \\
\hline SR-Learn & $\begin{array}{l}\text { - } \text { content repository } \\
\text { - member directory } \\
\text { notification; }\end{array}$ & $\begin{array}{l}\text { - Android app } \\
\text { - elearning platform for farmers in sheep } \\
\text { and goat industry } \\
\text { connects to users existing CARDI account } \\
\text { - last update Oct. } 2016\end{array}$ & \\
\hline
\end{tabular}

Strategy 3: Choose a Commercial Platform/Free or Upgrade

Download PDF (3.3 Strategy 3 Choose a Commercial Platform) 


\begin{tabular}{|c|c|c|c|}
\hline ICT Platform & Toolset & Key Features & Pricing Plan \\
\hline $\begin{array}{l}\text { FrontlineSMS } \\
\qquad \begin{array}{l}\text { IO/ } \\
\text { FRONTLINESMS }\end{array}\end{array}$ & $\begin{array}{l}\text { - } \text { SMS } \\
\text { - } \text { database } \\
\text { - } \text { API integration } \\
\text { - } \text { analytics }\end{array}$ & $\begin{array}{l}\text { - Desktop platform with mobile app } \\
\text { - } \text { can be used without internet connection } \\
\text { - } \text { auto-forward to email } \\
\text { - contact database } \\
\text { - } \text { scheduling } \\
\text { - keyword interactivity } \\
\text { - database import/export } \\
\text { - } 3^{\text {rd }} \text { party API integration } \\
\text { custom workflows (cost) }\end{array}$ & $\begin{array}{l}\text { Free with } \\
\text { tiered monthly } \\
\text { subscription } \\
\text { above } 250 \\
\text { messages } \\
\text { month }\end{array}$ \\
\hline $\begin{array}{l}\text { Textit } \\
\text { text it }\end{array}$ & $\begin{array}{ll}\text { - } & \text { SMS } \\
\text { - } & \text { IVR } \\
\text { - } & \text { database } \\
\text { - } & \text { API integration } \\
\text { analytics }\end{array}$ & $\begin{array}{l}\text { - } \text { Desktop platform with mobile app } \\
\text { - } \text { SMS notifications for individuals or groups } \\
\text { - design workflows with visual interface } \\
\text { - } \text { keyword interactivity } \\
\text { - } \text { scheduling } \\
\text { - } \text { contact database } \\
\text { - } 3^{\text {rd }} \text { party API integration }\end{array}$ & $\begin{array}{l}\text { Free } 1000 \\
\text { messaging } \\
\text { credits; } \\
\text { purchase } \\
\text { additional } \\
\text { credits } \\
\$ 20 / \$ 40 / \$ 140\end{array}$ \\
\hline Ushahidi & $\begin{array}{l}\text { - } \text { geomapping } \\
\text { - } \text { SMS } \\
\text { - } \text { photo sharing } \\
\text { - } \text { notification } \\
\text { - } \text { visualization tool } \\
\text { API integration }\end{array}$ & $\begin{array}{l}\text { - Desktop platform with mobile app (Android, } \\
\text { iPhone) } \\
\text { - } \text { crowdmapping platform } \\
\text { - data management features } \\
\text { - } 3^{\text {rd }} \text { party app integration } \\
\text { - } \text { notifications by email } \\
\text { - } \text { tagmissions by SMS or mobile app } \\
\text { - database import/export(?) }\end{array}$ & $\begin{array}{l}\text { Free basic; } \\
\text { \$99/mo or } \\
\text { \$499/mo for } \\
\text { additional } \\
\text { features }\end{array}$ \\
\hline * slack & $\begin{array}{l}\text { - } \text { messaging } \\
\text { - } \text { group messaging } \\
\text { - } \text { search tool repository } \\
\text { - } \text { document editor } \\
\text { - } \text { file sharing } \\
\text { - } \text { notification } \\
\text { - } \text { API integration }\end{array}$ & $\begin{array}{l}\text { - Desktop platform with mobile app (Android, } \\
\text { iPhone) } \\
\text { - team communication and collaboration } \\
\text { - private or group messaging } \\
\text { - } \text { file sharing and collaboration } \\
\text { - } \quad 3^{\text {rd }} \text { party app integration }\end{array}$ & $\begin{array}{l}\text { Free basic; } \\
\text { \$8-15/per } \\
\text { user per } \\
\text { month } \\
\text { depending on } \\
\text { features }\end{array}$ \\
\hline
\end{tabular}

\section{Strategy 4: Patch Pieces Together}

Download PDF (3.3 Strategy 4 Patch Pieces Together) 


\begin{tabular}{|c|c|c|c|}
\hline ICT Platform & Toolset & Key Features & Pricing Plan \\
\hline $\begin{array}{l}\text { Zapier } \\
\qquad \text { zapier }\end{array}$ & - API integration & 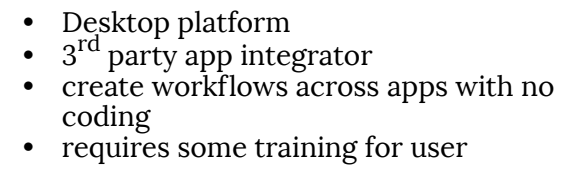 & $\begin{array}{l}\text { Free basic; } \\
\$ 20-\$ 250 / \\
\text { month for } \\
\text { additional } \\
\text { features }\end{array}$ \\
\hline IFTTT & - API integration & $\begin{array}{l}\text { - Desktop platform } \\
\text { - } 3^{\text {rd }} \text { party app integrator } \\
\text { create workflows across apps with no } \\
\text { coding } \\
\text { - requires some training for user }\end{array}$ & Free \\
\hline
\end{tabular}




\section{Worksheet 3.4: Matching the Tools with the Platform}

Having decided on a technology acquisition strategy, the next step is to identify the range of ICT platforms that include the tool(s) needed for your campaign. When completed, this table makes it easy to compare ICT platforms offering similar tools.

In the left-hand column, list the ICT tool(s) you identified on worksheet 3.1. In the middle column, list the ICT platforms that include the tool(s) in the first column. Add notes about features, cost, etc., in the last column.

Download PDF (3.4 Matching Tools with Platform)

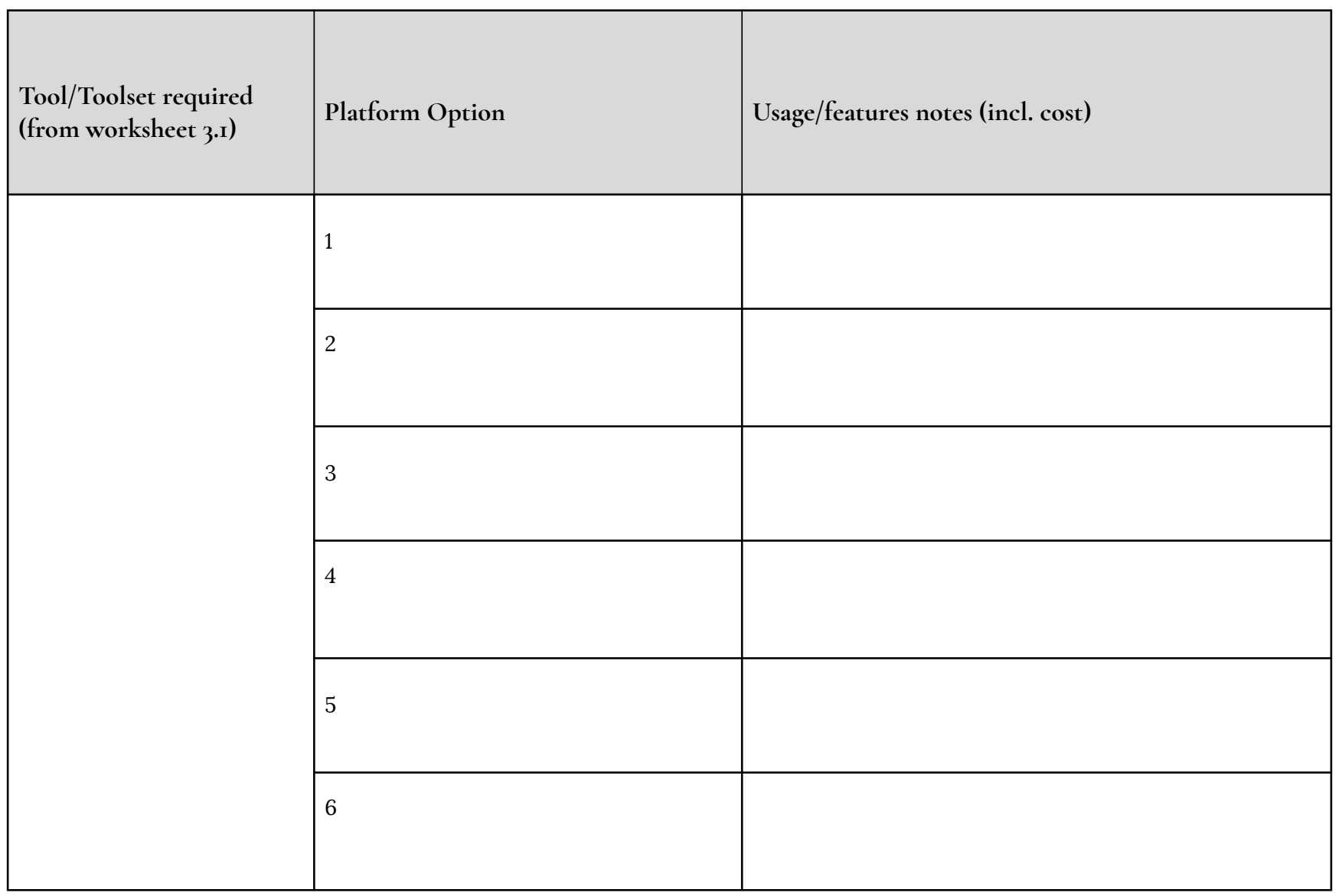




\section{Worksheet 3.5: Evaluate the Platform}

On the previous table, each ICT platform is assigned a number from 1-6. Using that numbering system, circle the platform number(s) that you feel are best rated for each of the statements in this table. You can circle more than one platform in each row.

Compare the results after you complete this worksheet. Which platform number is most often circled? Is this the best choice for the campaign? What is the second-best choice?

Download PDF worksheet (3.5 Evaluate the Platform)

Fit for purpose

The platform has the tool we need for the campaign

The features of the tool(s) appear to be adequate

It is easy to configure (set up, maintain, operate)

It is easy for community members to use

\section{Platform Number}

Integration

It can be integrated with ICT the community has already

$\begin{array}{llllll}1 & 2 & 3 & 4 & 5 & 6\end{array}$

We can integrate it with other platforms/tools

if needed

$\begin{array}{llllll}1 & 2 & 3 & 4 & 5 & 6\end{array}$

It is easy to integrate with other platforms / tools

$\begin{array}{llllll}1 & 2 & 3 & 4 & 5 & 6\end{array}$

It does not rely on another platform to function

$\begin{array}{llllll}1 & 2 & 3 & 4 & 5 & 6\end{array}$




\section{Performance}

It can support enough users for the campaign

It allows for multiple administrators/profiles

It will scale up to meet our needs if it is successful $\begin{array}{llllll}1 & 2 & 3 & 4 & 5 & 6\end{array}$

$\begin{array}{llllll}1 & 2 & 3 & 4 & 5 & 6\end{array}$

$\begin{array}{llllll}1 & 2 & 3 & 4 & 5 & 6\end{array}$

\section{Pricing}

\begin{tabular}{|c|c|c|c|c|c|}
\hline It is affordable for the campaign & 1 & 2 & 3 & 4 & 5 \\
\hline It is affordable if we need to grow/scale up & 1 & 2 & 3 & 4 & 5 \\
\hline $\begin{array}{l}\text { Using this platform will not incur a cost burden } \\
\text { for users }\end{array}$ & 1 & 2 & 3 & 4 & 5 \\
\hline $\begin{array}{l}\text { We do not need to request funds to try it for the } \\
\text { campaign }\end{array}$ & 1 & 2 & 3 & 4 & 5 \\
\hline
\end{tabular}

\section{Vendor}

The vendor has a good reputation (check reviews)

The vendor provides good support (check reviews)

We can accept the terms of service/end-user agreement

We can move our data to another platform later $\begin{array}{llllll}1 & 2 & 3 & 4 & 5 & 6\end{array}$

$\begin{array}{llllll}1 & 2 & 3 & 4 & 5 & 6\end{array}$

$\begin{array}{llllll}1 & 2 & 3 & 4 & 5 & 6\end{array}$

$\begin{array}{llllll}1 & 2 & 3 & 4 & 5 & 6\end{array}$

\section{Security}

The platform is secure enough for our purpose

The security features or policies do not present barriers to our activities

\section{$\begin{array}{llllll}1 & 2 & 3 & 4 & 5 & 6\end{array}$}

$\begin{array}{llllll}1 & 2 & 3 & 4 & 5 & 6\end{array}$ 
Other considerations

$\begin{array}{llllll}1 & 2 & 3 & 4 & 5 & 6\end{array}$

$\begin{array}{llllll}1 & 2 & 3 & 4 & 5 & 6\end{array}$ 


\section{Worksheet 3.6: Prepare and Test the Prototype}

Prototyping is the stage where we configure and test the ICT platform. In this step, we configure the tool(s) on the platform to perform the activity as depicted in our Use-Case Scenario. We test the configuration and fix any problems before launching the campaign.

Use this table to list the activities from your Use-Case Scenario, match them with the tool(s) on the chosen ICT platform, then add any configuration notes. Check 'OK' in the Test Results column after the tool has been tested and is working as it should.

ICT Platform: FrontlineSMS

\begin{tabular}{|l|l|l|l|}
\hline Activity & Tool/Feature & Configuration Notes & Test Results \\
\hline $\begin{array}{l}\square \text { farmer subscribes to } \\
\text { receive messages } \\
\begin{array}{l}\square \text { keyword function: 'subscription } \\
\text { using SMS' }\end{array}\end{array}$ & $\begin{array}{l}\text { Activity name: Join farmers group } \\
\text { Create new group 'Farmers' } \\
\text { Add welcome text }\end{array}$ & $\begin{array}{l}\square \text { OK } \\
\square \text { forgot to create group } \\
\square \text { tested on mock phone }\end{array}$ \\
\hline$\square$ & $\square$ & $\square$ OK & $\square$ OK \\
\hline$\square$ & $\square$ & & \\
\hline
\end{tabular}

Prototyping and Testing Worksheet

Download PDF (3.6 Prototyping and Testing)

ICT Platform: 


\begin{tabular}{|l|l|l|}
\hline Activity & Tool/Feature & Configuration Notes \\
\hline$\square$ & $\square$ & $\square$ ОК \\
\hline$\square$ & $\square$ & $\square$ ОК \\
\hline$\square$ & $\square$ & $\square$ ОК \\
\hline$\square$ & $\square$ & $\square$ ОК \\
\hline$\square$ & $\square$ & $\square$ ОК \\
\hline
\end{tabular}




\title{
SESSION 4: PLANNING AND MANAGING A CAMPAIGN
}

\section{WORKSHEETS}

\author{
4.1: Planning Timeline and Checkpoints \\ 4.2: Campaign Planning Checklist \\ 4.3: Creating a Campaign Evaluation Plan \\ 4.4: Collecting Information \\ 4.5: Managing the Campaign \\ 4.6: Reporting Back to the Community
}




\section{Worksheet 4.I: Planning Timeline and Checkpoints}

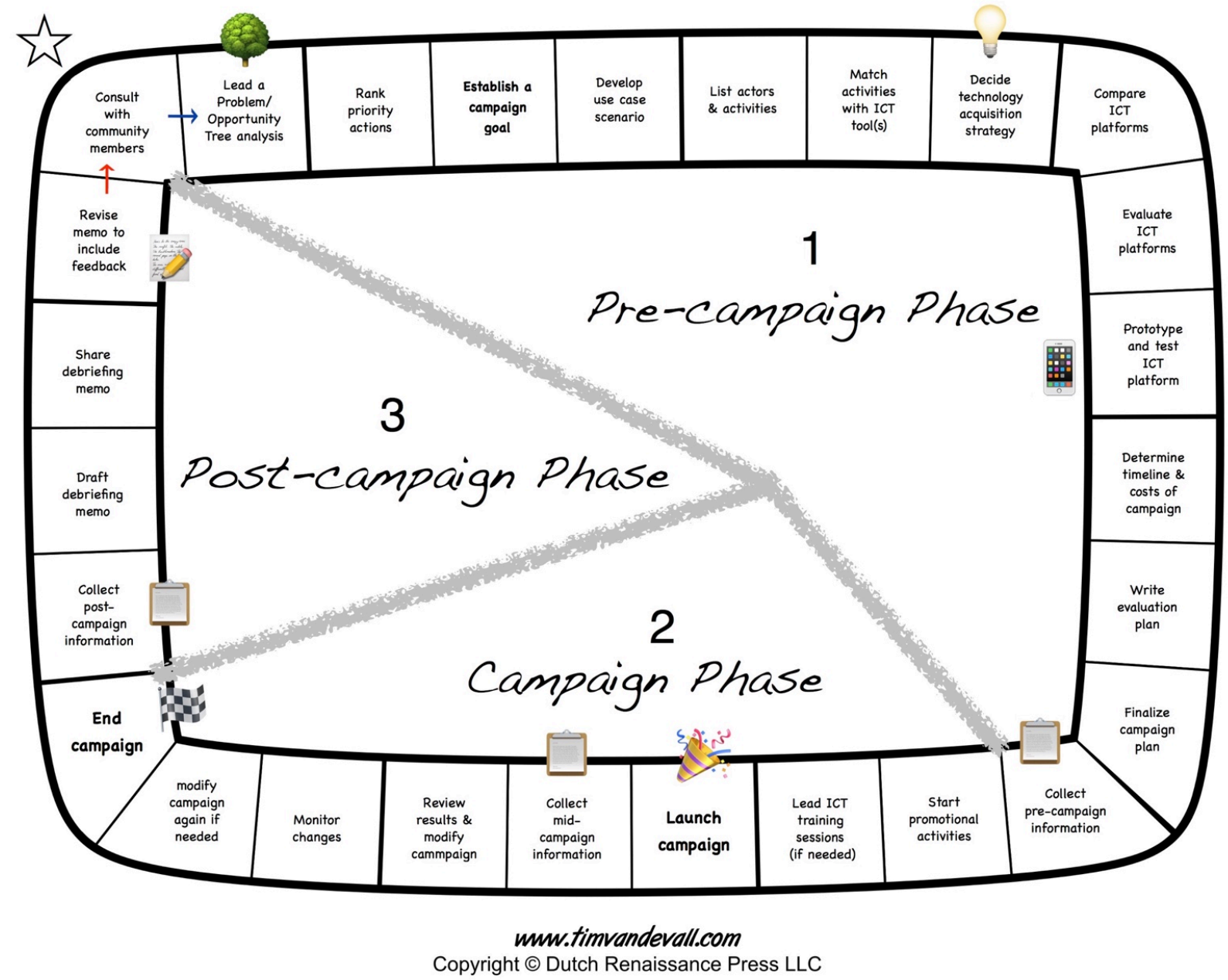

Download PDF (4.1 Planning Timeline and Checkpoints) 


\section{Worksheet 4.2: Campaign Planning Checklist}

Download PDF (4.2 Campaign Planning Checklist)

\section{Timing and Timeline}

Will you be ready for the demands on your time and attention when you launch the campaign?

What external events, seasonal activities, or community schedules do you need to consider?

How long will the campaign need to run?

\section{Implementation: Plan for the change process}

Who will be your main partners and/or community champions during the campaign?

Have you received any formal approval that you might need from the community and/or sponsor to run the campaign?

Will you need to provide any ICT training to community members before the campaign begins? 


\section{Promotion, costs, community data}

How will you make community members aware of the campaign?

How many community members do you expect to participate in the campaign?

Have you calculated all the costs associated with the campaign?

ICT-related costs to you and/or the sponsor?

ICT-related costs to community members?

Other costs to you and/or the sponsor?

Other costs to community members?

\section{Security and privacy}

Who will have administrative access to the ICT platform? How will you manage admin access?

Have you identified and made plans to mitigate any information security or privacy concerns related to ICT use during the campaign?

Will you need pre-approval to share or disclose user information in the debrief memo? 


\section{Learning: Plan for evaluation}

Have you created an evaluation plan?

Do you have the resources you will need to collect evaluation information for the campaign?

Do you have a backup plan if the campaign runs into unexpected difficulties?

\section{Ending the Campaign}

Have you collected all the information you need for your evaluation plan?

What is the status of the ICT Continue using it

platform?

\section{Continue using it}

Shut it down and try something else

Pause and consult with community

Will you need to make any changes to admin access on the ICT platform? Is user data secure? 


\section{Worksheet 4.3: Creating a Campaign Evaluation Plan}

Following the principle of "Understand failure/build on success" it is important for the Tech Steward to create an evaluation plan for the campaign.

"Evaluation is primarily concerned with determining the merit, worth or value of an established policy or planned intervention."

-Hall, I., D. Hall (2004). Evaluation and Social Research. Palgrave. (p.28)

Evaluation of a campaign is essential for the Tech Steward, the community, and sponsor to understand failure and build on success.

Evaluation has three essential features:

- it is a systematic collection of information, distinguished from casual observation and biased reporting, leading to

- an informed judgement about the value of the program being evaluated, providing

- evidence to aid decision making about next steps.

Creating an evaluation plan starts with the Tech Steward asking five key questions early in the pre-campaign phase:

1. What is the campaign goal?

2. When or how will we know if we have achieved it (metrics)?

3. Where will I get information (data) to assess the outcome of the campaign?

4. What methods can I use to collect that information?

5. Who can help me answer these questions? (use the knowledge around you)

From the previous sessions, we know that a well-defined campaign goal has three key ingredients:

A specific outcome for the campaign, for a specific activity with a specific community of practice.

We know if we have achieved the outcome by observing what happens during the campaign. We can measure effectiveness using four categories of metrics:

- Interaction: the amount of activity on the ICT platform during the campaign. How many people joined the group? How many people posted messages? How many messages were posted? What time of day/day of week was activity most frequent? Do you see any patterns in the activity? Can you think of other measures of interaction?

- Engagement: the type of activity on the ICT platform during the campaign. This is a more qualitative measure looking at the content of the interactions, such as the types of messages posted and types of content shared, uploaded, rated, commented on, etc. Can you think of any measures of engagement?

- Influence: the impact of the campaign relative to other methods of interaction and engagement. How many people are aware of the campaign? How many are participating (actively or passively) in the campaign? Has the campaign changed perceptions of ICT use? Has the campaign changed attitudes or perceptions of community members in relation to its intended outcome?

- Behaviour change: the impact of the campaign on observable practices in relation to the intended outcome. Are community members doing things differently? Have they changed their communication practices? Has the campaign led to observable changes in professional or business practices of the community members in relation to its intended outcome?

- Can you think of any other types of metrics that this list might have missed? 
The evaluation plan is divided into three phases. Evaluation-related questions are asked and information is collected during each phase:

- Pre-campaign (achieve readiness)

- Mid-campaign (monitor and modify)

- Post-campaign (gather and report)

The Tech Steward should also consider four key influences on a campaign:

- The community members

- The sponsor

- The technology

- The Tech Steward

We combine these elements into an evaluation framework for planning.

The Evaluation Planning Table Sample below (Download PDF Campaign Goal Worksheet 4.3) provides a worksheet for organizing the evaluation plan for a campaign. Use the blank worksheet to organize the evaluation plan for your campaign.

Improve the timeliness and reduce costs of exchanging messages between Extension officer and community members when scheduling meetings and responding to questions from veg. farmers in St. George County

Sample Campaign Goal Worksheet: Improve the timeliness and reduce costs of exchanging messages between Extension Officer and community members when scheduling meetings and responding to questions from veg. farmers in St. George County. 


\begin{tabular}{|c|c|c|c|c|}
\hline $\begin{array}{l}\text { What results do we expect to } \\
\text { observe from this campaign? }\end{array}$ & Metric & Source of data & Method & $\begin{array}{l}\text { Collect this data } \\
\text { when? }\end{array}$ \\
\hline $\begin{array}{l}\text { Community members will be } \\
\text { more aware of upcoming } \\
\text { meetings; more community } \\
\text { members will attend meetings }\end{array}$ & $\begin{array}{ll}\text { - } & \text { Interaction } \\
\text { - } & \text { Engagement } \\
\text { - } & \text { Influence } \\
\text { - } & \text { Behaviour } \\
\text { - Other }\end{array}$ & $\begin{array}{l}\text { - } \text { Community members } \\
\text { - ICT platform } \\
\text { - Sponsor } \\
\text { - } \text { Steward's notes } \\
\text { Other }\end{array}$ & $\begin{array}{l}\text { Count and compare } \\
\text { attendance at } \\
\text { meetings }\end{array}$ & $\begin{array}{l}\text { - } \text { Pre-campaign } \\
\text { - } \text { Mid-campaign } \\
\text { - } \text { Post-campaign }\end{array}$ \\
\hline $\begin{array}{l}\text { The Extension officer (Me) will } \\
\text { save some time and money on } \\
\text { unnecessary travel }\end{array}$ & $\begin{array}{ll}\text { - } & \text { Interaction } \\
\text { - } & \text { Engagement } \\
\text { - } & \text { Influence } \\
\text { - } & \text { Behaviour } \\
\text { - } & \text { Other }\end{array}$ & $\begin{array}{l}\text { - } \text { Community members } \\
\text { - ICT platform } \\
\text { - Sponsor } \\
\text { - Steward's notes } \\
\text { Other }\end{array}$ & $\begin{array}{l}\text { Track cost and travel } \\
\text { time; calculate } \\
\text { savings }\end{array}$ & $\begin{array}{l}\text { - } \text { Pre-campaign } \\
\text { - } \text { Mid-campaign } \\
\text { - } \text { Post-campaign }\end{array}$ \\
\hline $\begin{array}{l}\text { Community members will use the } \\
\text { group chat to send the Extension } \\
\text { officer (me) questions }\end{array}$ & $\begin{array}{ll}\text { - } & \text { Interaction } \\
\text { - } & \text { Engagement } \\
\text { - } & \text { Influence } \\
\text { - } & \text { Behaviour } \\
\text { - } & \text { Other }\end{array}$ & $\begin{array}{l}\text { - } \text { Community members } \\
\text { - ICT platform } \\
\text { - Sponsor } \\
\text { - Steward's notes } \\
\text { - Other }\end{array}$ & $\begin{array}{l}\text { Ask members about } \\
\text { their intention to use } \\
\text { the chat; count } \\
\text { number of posts; } \\
\text { examine content of } \\
\text { the posts on the group } \\
\text { chat }\end{array}$ & $\begin{array}{l}\text { - } \text { Pre-campaign } \\
\text { - } \text { Mid-campaign } \\
\text { - } \text { Post-campaign }\end{array}$ \\
\hline $\begin{array}{l}\text { Community members will find } \\
\text { the chat a useful service that } \\
\text { saves them time and improves } \\
\text { interactions with me and others; }\end{array}$ & $\begin{array}{ll}\text { - } & \text { Interaction } \\
\text { - } & \text { Engagement } \\
\text { - Influence } \\
\text { - } \text { Behaviour } \\
\text { Other }\end{array}$ & $\begin{array}{l}\text { - } \text { Community members } \\
\text { - ICT platform } \\
\text { - Sponsor } \\
\text { - Steward's notes } \\
\text { - Other }\end{array}$ & $\begin{array}{l}\text { Get feedback from the } \\
\text { community members }\end{array}$ & $\begin{array}{l}\text { - } \text { Pre-campaign } \\
\text { - } \text { Mid-campaign } \\
\text { - } \text { Post-campaign }\end{array}$ \\
\hline
\end{tabular}

Download PDF (‥3 Campaign Goals): 


\begin{tabular}{|c|c|c|c|c|}
\hline $\begin{array}{l}\text { What results do we expect to } \\
\text { observe from this campaign? }\end{array}$ & Metric & Source of data & Method & $\begin{array}{l}\text { Collect this data } \\
\text { when? }\end{array}$ \\
\hline & $\begin{array}{ll}\text { - } & \text { Interaction } \\
\text { - } & \text { Engagement } \\
\text { - } & \text { Influence } \\
\text { - } & \text { Behaviour } \\
\text { Other }\end{array}$ & $\begin{array}{ll}\text { - } & \text { Community members } \\
\text { - ICT platform } \\
\text { Sponsor } \\
\text { - Steward's notes } \\
\text { Other }\end{array}$ & & $\begin{array}{l}\text { - Pre-campaign } \\
\text { - Mid-campaign } \\
\text { Post-campaign }\end{array}$ \\
\hline & $\begin{array}{ll}\text { - } & \text { Interaction } \\
\text { - } & \text { Engagement } \\
\text { - } & \text { Behavionce } \\
\text { - } & \text { Other }\end{array}$ & $\begin{array}{ll}\text { - } & \text { Community members } \\
\text { - ICT platform } \\
\text { Sponsor } \\
\text { - Steward's notes } \\
\text { Other }\end{array}$ & & $\begin{array}{ll}\text { - } & \text { Pre-campaign } \\
\text { - } & \text { Mid-campaign } \\
\text { Post-campaign }\end{array}$ \\
\hline & $\begin{array}{ll}\text { - } & \text { Interaction } \\
\text { - } & \text { Engagement } \\
\text { - } & \text { Behaence } \\
\text { - } & \text { Other }\end{array}$ & $\begin{array}{ll}\text { - } & \text { Community members } \\
\text { - ICT platform } \\
\text { Sponsor } \\
\text { - Steward's notes } \\
\text { Other }\end{array}$ & & $\begin{array}{l}\text { - Pre-campaign } \\
\text { - Mid-campaign } \\
\text { Post-campaign }\end{array}$ \\
\hline & $\begin{array}{ll}\text { - } & \text { Interaction } \\
\text { - } & \text { Engagement } \\
\text { - Influence } \\
\text { - } & \text { Behaviour } \\
\text { Other }\end{array}$ & $\begin{array}{ll}\text { - } & \text { Community members } \\
\text { - ICT platform } \\
\text { Sponsor } \\
\text { - Steward's notes } \\
\text { Other }\end{array}$ & & $\begin{array}{l}\text { - Pre-campaign } \\
\text { - } \text { Mid-campaign } \\
\text { Post-campaign }\end{array}$ \\
\hline
\end{tabular}




\section{Worksheet 4.4: Collecting Information}

Pre-campaign information is often needed to provide baseline data for comparison later.

Use this table to organize all the pre-campaign information collection methods list in the Evaluation Planning Table (‥4 Collecting Information)

Pre-Campaign:

\begin{tabular}{|l|l|l|}
\hline Source & Method & Resources \\
\hline Community members & & \\
\hline ICT Platform & & \\
\hline Sponsor & & \\
\hline Steward's notes & & \\
\hline
\end{tabular}

Pre-campaign information is often needed to obtain feedback from community members and to make changes during the campaign. This is particularly important if the campaign is not proceeding as expected.

Use this table to organize all the mid-campaign information collection methods list in the Evaluation Planning Table.

\section{Mid-Campaign:}




\begin{tabular}{|l|l|l|}
\hline Source & Method & Resources \\
\hline Community members & & \\
\hline ICT Platform & & \\
\hline Sponsor & & \\
\hline Steward's notes & & \\
\hline
\end{tabular}

Post-campaign information is needed to obtain feedback from community members to evaluate the outcome in relation to the campaign goal. This is particularly important for providing feedback to the community and sponsor about the results of the campaign. It also provides evidence to assist with decisions about next steps.

Use this table to organize all the pre-campaign information collection methods list in the Evaluation Planning Table.

Post-Campaign:

\begin{tabular}{|l|l|l|}
\hline Source & Method & Resources \\
\hline Community members & & \\
\hline ICT Platform & & \\
\hline Sponsor & & \\
\hline Steward's notes & & \\
\hline
\end{tabular}




\section{Worksheet 4.5: The Campaign Plan}

The campaign plan is a summary of the details that have been worked out in the various steps so far.

It is a single, short document that can be shared with community members and sponsor for feedback prior to starting a campaign.

You will find a template for the campaign plan on the next page. The plan should include each section but keep it short and concise. It should summarize the results of the planning process you have now completed.

Campaign Planning Template

Campaign Goal (2.5 a Translating Means into Action)

Describe the goal of the campaign. Include the three important details: (1) the specific goal; (2) the primary action; (3) the community of practice.

The goal of the campaign is to [objective] by using ICT to [priority action] for [community of practice].

\section{ICT-platform for the campaign (3.5 Evaluate the Platform, 3.6 Prototyping and Testing)}

Describe the ICT platform chosen for the campaign. What tool(s) does it include and what activities will it support? What features and functions will be used? If a contact or a database needs to be created for the campaign, how will that happen? How will the database need to be organized? (e.g., will you need to create separate groups). Who will have administrator access to the ICT platform before/during/after the campaign?

\section{Scale and Scope of the Campaign (2.3 Community Characteristics)}

Describe the anticipated scope, scale, and characteristics of the community of practice or user group that will be involved in the campaign (include both senders and receivers of messages). How many people will be participating? How much ICT interaction (e.g., messages being sent, content items being posted) might be expected during the campaign? What is the anticipated cost of messaging or other interactions for users and for the Tech Steward and/or sponsor?

\section{Timeline (4.1 Planning Timeline and Checkpoints, $\underline{4.2}$ Campaign Planning Checklist)}

Describe the preferred starting and end dates of the campaign. Explain or indicate any important factors related to the timeline (e.g., seasonal opportunities, deadlines, etc.). Will the campaign run continuously, or is it a single action campaign? (e.g., email blast). List the key steps and deadlines for each stage of planning, implementing, and evaluating the campaign.

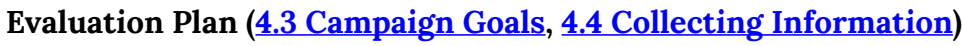

Describe briefly how the outcome of this campaign will be assessed against the campaign goal. What kind of baseline information will you need to collect before starting the campaign? What kind of information will you need to collect during the campaign? What kind of information will you need to collect after the campaign? How will you obtain this information?

\section{Resourcing and Promotional Activities (4.2 Campaign Planning Checklist)}

List financial, technical, and human resources required to accomplish the campaign. If costs are adding up, what 
alternatives are available to reduce the campaign budget? Describe how the campaign will be promoted to the community, by whom, and what financial or human resources may be required to do so (e.g., creating posters)

\section{Questions and Concerns}

Describe or list any questions or concerns related to the campaign that you feel need further clarification during planning and before starting the campaign. Do you need any technical support? Do you need help with creating your evaluation plan? Are there any privacy, security or other risk issues to consider? How will you mitigate them? Can you reach out to another Tech Steward, or someone else, to help you answer these questions? 


\section{Worksheet 4.6: Reporting Back to the Community}

After the campaign, the Tech Steward prepares a debriefing memo for the community. This is a short document very similar to the campaign plan reflecting on results and outcomes.

The memo should be concise and no longer than two pages. It can be posted online as a blog post, distributed as a hardcopy, or a digital document.

The memo provides an opportunity for community feedback and reflection on the outcome of the campaign in relation to its goal. It is essential for having conversations with the community members and the sponsor about next steps.

It is recommended that the Tech Steward organize a community meeting to discuss a draft version of the debriefing memo with community members. Ask for feedback on the document, especially the next steps. Revise the document to include feedback from the community members and then share the final memo.

You will find a template for the debriefing memo below. It is nearly identical in structure to the campaign plan document.

Where appropriate, details from the campaign plan can simply be copied into the debrief memo to save time. However, note that the questions asked in the debrief memo are results and outcome-oriented.

The memo should include each section but keep it brief and to the point as a summary rather than an in-depth report.

Campaign Debriefing Memo Template:

\section{Campaign Goal}

Restate the goal of the campaign. Include the three important details: (1) the specific goal; (2) the primary action; (3) the community of practice.

The goal of the campaign is to [objective] by using ICT to [priority action] for [community of practice].

\section{ICT-platform chosen for the campaign}

Describe the ICT platform chosen for the campaign. What tool(s) does it include and what activities will it support? What features and functions were used? If a contact or a database needs to be created for the campaign, how was that created? How was the database organized? (e.g., did you need to create separate groups, or categories?). Who administered access to the ICT platform before/during/after the campaign? Was the ICT platform secure? Did it present any privacy concerns during the campaign?

\section{Scale and Scope of the Campaign}

Describe scope, scale, and characteristics of the community of practice or user group that was involved in the campaign (include both senders and receivers of messages). How many people did you expect to participate? How much ICT interaction (e.g., messages being sent, content items being posted) did you expect during the campaign? What was the anticipated cost of messaging or other interactions for users and for the Tech Steward and/or sponsor?

\section{Timeline}


Describe the preferred starting and end dates of the campaign. Explain or indicate any important factors related to the timeline (e.g., seasonal opportunities, deadlines, etc.). Will the campaign run continuously, or is it a single action campaign? (e.g., email blast). List the key steps and deadlines for each stage of planning, implementing, and evaluating the campaign.

\section{Resourcing and Promotional Activities}

List financial, technical, and human resources that were required to accomplish the campaign. If costs were too high, what alternatives did you try to reduce the campaign budget? Describe how the campaign was promoted to the community, by whom, and what financial or human resources were required to do so (e.g., creating posters). Did you need assistance with the campaign?

\section{Evaluation and Results}

Describe briefly how the outcome of this campaign was assessed against the campaign goal. What kind of baseline information did you collect before starting the campaign? What kind of information did you collect during the campaign? What kind of information did you collect after the campaign? How did you obtain this information?

\section{Next Steps}

Describe or list any outstanding questions or concerns related to the campaign that you feel need further clarification. What is the next step for the community? Continue with the ICT platform and integrate it into regular practice. Modify the ICT platform and campaign plan based on the results and try another campaign? Abandon the ICT platform and try something else? What did you learn about the community members and their communication practices? Do community members have any suggestions for a new or different campaign?

77 | Worksheet 4.6: Reporting Back to the Community 